\title{
الصعوبات التي تواجهها الهيئات المحلية في إعداد الخطط التنموية الإستراتيجية وسبل الثنفلب عليها بالتطبيق على بلديات محافظات شمال الضفة الفربية التفالية
}

Challenges Facing the Local Authorities in Preparing the Strategic Development Plans and Ways to Overcome Them Through Implementation

\section{at the Municipalities of the Northern Governorates in West Bank}

\author{
Dr. Salah Y. Sabri \\ Assistant Professor/Al-Quds Open University/Palestine \\ ssabri@qou.edu
}

Dr. Shaher M. Obaid

Associate Professor/AI-Quds Open University/Palestine sobaid@qou.edu

Dr. Atieh M. Musleh

Associate Professor/Al-Quds Open University/Palestine amusleh@qou.edu

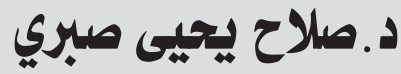 \\ أستاذ مساعد/ جامعة القدس المفتوحة / فلسطين
}

د.

أستاذ مشارك / جامعة القدس المفتوحة/ فلسطين

|c.

أستاذ مشارك / جامعة القدس المفتوحة/ فلسطين
Received: 1/ 12/ 2018, Accepted: 23/ 2/ 2019 DOI:

http: I/journals.qou.edu/index.php/eqtsadia
تاريخ الاستلام: 12/ 12/ 2018م، تاريخ القبول: 23/ 23 / 2019 2019. E - ISSN: 2410 - 3349 P - ISSN: 2313 - 7592 
local government classification, town/city population, and the number of employees in the local government. However, there were no differences due to the local government title.

There was a negative correlation between the age of the local government and the challenges it encountered. The most important means of overcoming these challenges are hiring a consulting team with experience in municipal development planning and benefiting from success stories in the field of municipal development planning. The study also recommended simplifying the developmental planning guide to include the main tools of planning and leave an opportunity for the local governments to adapt the tools, as well as providing material and moral incentives to the participants from the local community in the development plans, especially representatives of the local community and the private sector.

Keywords: Development Planning, Local Governments, Development in Palestine.

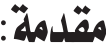

يعد التخطيط التنموي الاستراتيجي من عناصر نجاح

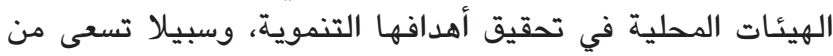

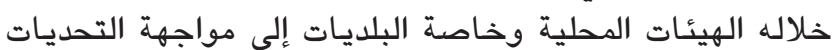
التي تواجهها من خلال عمل خطط تنموية تنطلق من احتياجات التهات

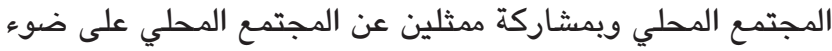

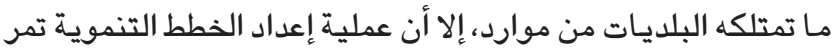

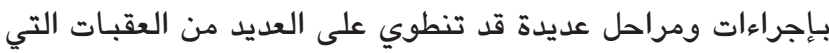

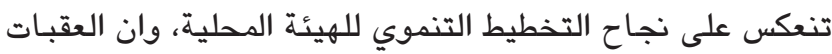

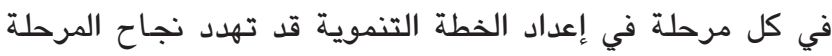

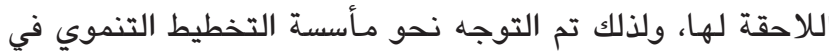

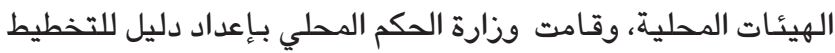

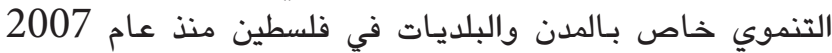

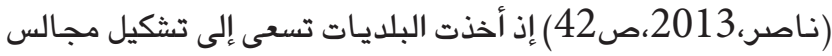

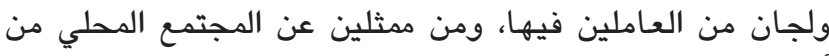

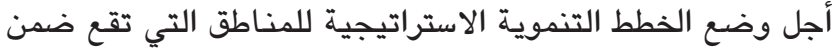

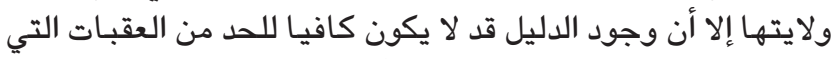

تقف في وجه إعداد الخطط التنموية أو التقليل من حدتهاد التها.

وتعد إدارة البلدية ممثلة بـالمجلس البلدي والعاملين في البلدية

من أهم العناصر الفاعلة في وضع الخطة التحارة التنموية الاستراتيجية

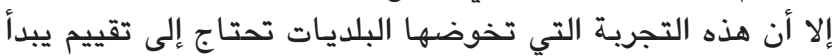

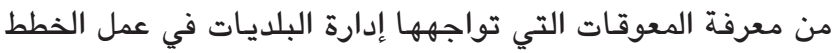
التنموية، وذلك من أجل الإسهام في تعزيز جودة التواجي التخطيط التنموي

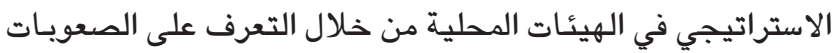

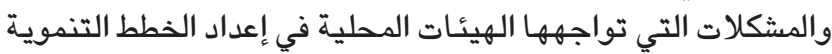

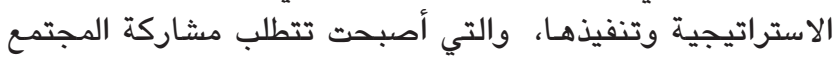

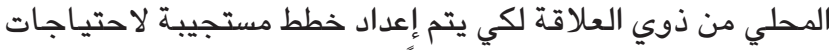

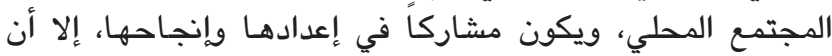

\section{|الخمص:}

هدفت الدراسة إلى معرفة الصعويـات التي تواجهها الهيئات المحلية في إعداد الخطط التنموية الإستراتيجية في معرفة بلديات التيات

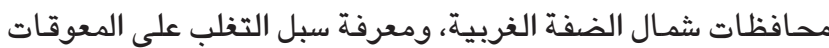

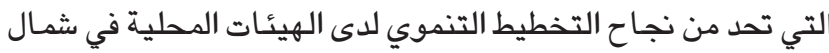

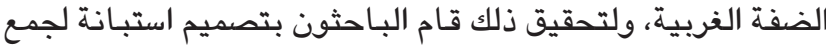

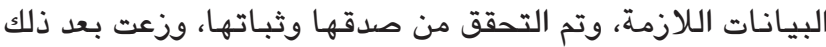

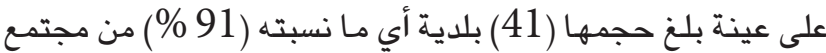

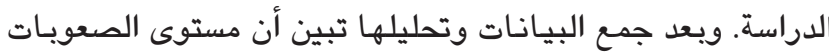

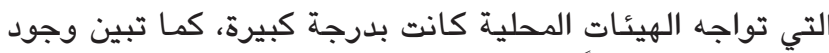

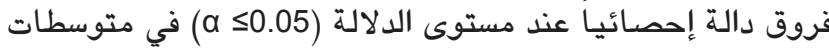
استجابـات أفراد العينة في الصعوبـات التي تواجهها الهيا الهيئات

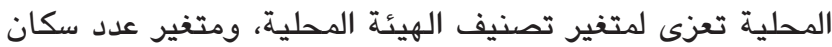

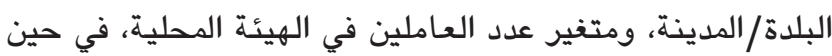
تبين عدم وجود فروق تعزى لمتغير اسم الهيئة المحلية.

كما تبين وجود علاقة خطية عكسية دالة إحصائياً بين عمر أحر

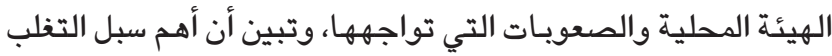

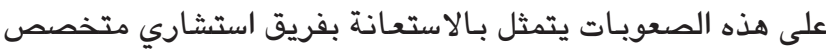

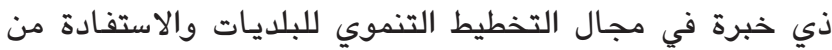

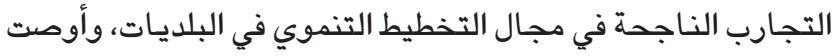

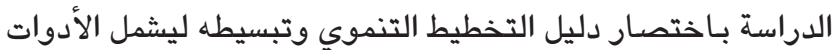

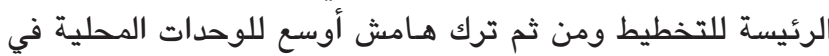

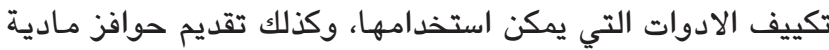

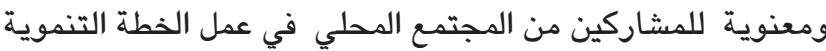

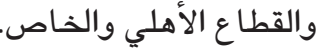

الكلمات المفتاحية: التخطيط التنموي،الهيئات المحلية

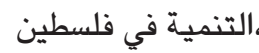

\section{Abstract}

The study aimed at identifying the challenges facing local authorities in preparing the strategic development plans at the municipalities in the northern governorates of the West Bank and ways of overcoming them. In order to achieve the objectives of the study, the researchers developed a tool to collect the required data (a questionnaire), and verified its validity and stability. A sample of 41 municipalities, which represents $91 \%$ of the study population, was selected for the study. Following the data collection and its analysis, it was found that the level of challenges faced by the local authorities was very high. Moreover, statistically significant differences were found at the level of $a \geq 0.05$ in the responses of the sample in the challenges faced by the local authorities due to the 
مواجهتها عند إعداد الخطط التنموية الاستراتيجية، لكون الخطط

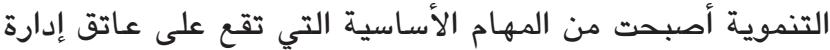

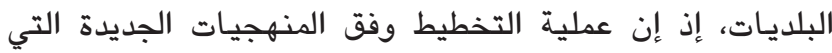

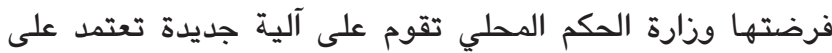

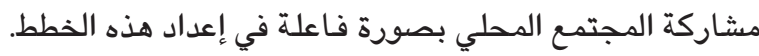
كما تكمن أهمية الدراسة بـأنها تعد توثيقاً للتجارب الذاتية

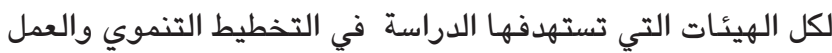

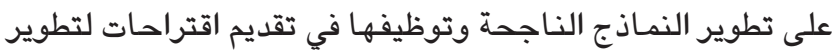
دليل التخطيط التنموي المحلي للمدن والبلدات الفلسطينية.

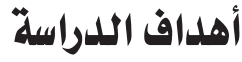

تسعى الدراسة إلى تحقيق مجموعة من الأهداف تشمل:

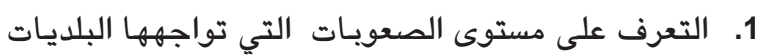

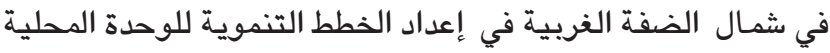

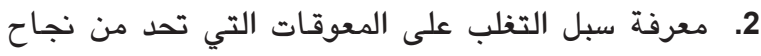

التخطيط التنموي لدى الهيئات المحلية في شمال الضفة الغرئية

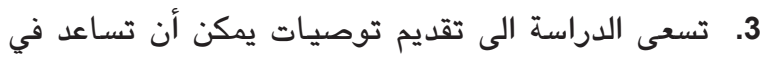

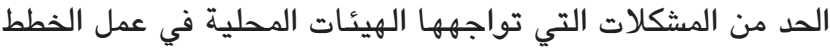
التنموية ويـالتالي تحسين جودة هذه الخطط.

\section{فرضيات اللدراسة:}

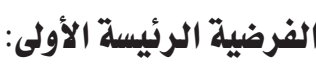

لا توجد فروق ذات دلالة إحصائية عند مستوى الدلالة

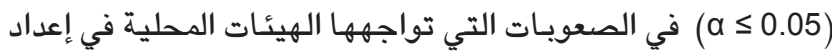

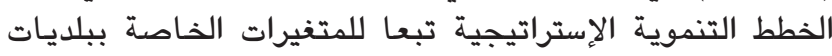

محافظات شمال الضفة الغربية.

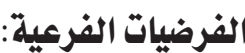

1.

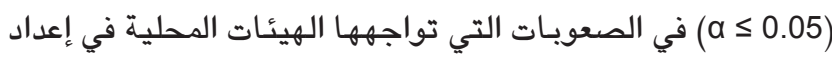

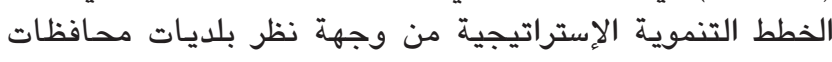
شمال الضفة الغربية تعزى لمتغير اسم المحافظة التي تقع فيهاتيها الهيئة المحلية.

2. ل ال توجد فروق ذات دلالة إحصائية عند مستوى الدلالة

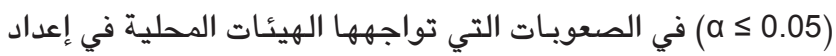

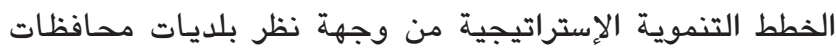

شمال الضفة الغربية تعزى لمتغير تصنيف الهيئة المحلية.

3. لا توجد فروق ذات دلالة إحصائية عند مستوى الدلالة

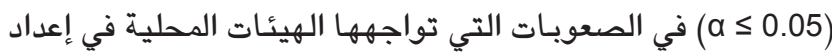

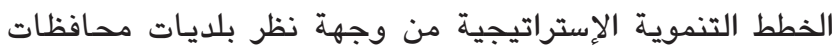
شمال الضفة الغربية تعزى لمتغير عدد السكان في البلدة/المدينة. 4. لا توجد فروق ذات دلالة إحصائية عند مستوى الدلالة

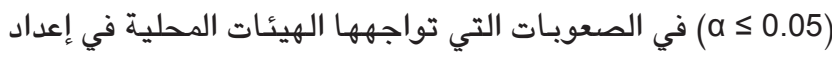
الخطط التنموية الإستراتيجية من وجهة نظر الفيات بلديات محافظات شمال الضفة الغربية تعزى لمتغير عدد العاملين في الهيئة المحلية.
العديد من الخطط التي تم عملها في السنوات السابقة وتم مشاركة

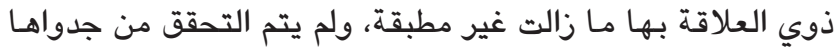

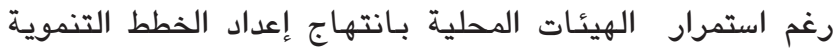
الإستراتيجية للسنوات القادمة.

\section{مشكلة الدراسة:}

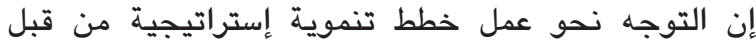

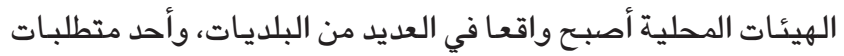

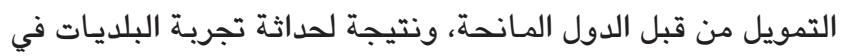

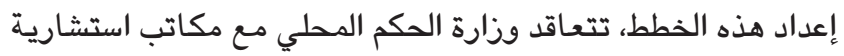

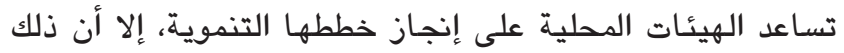

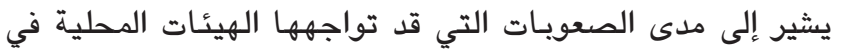

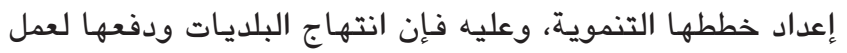

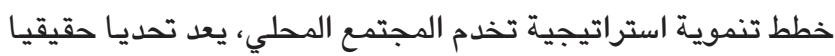

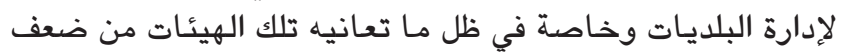

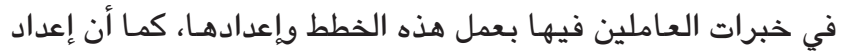

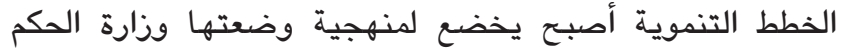

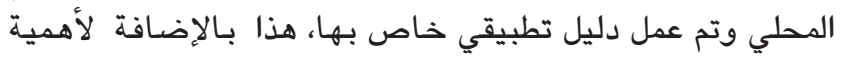

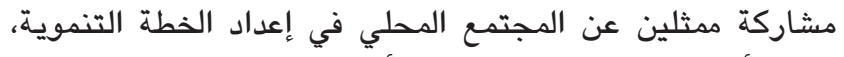

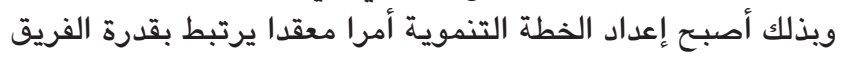

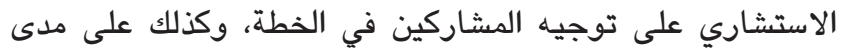

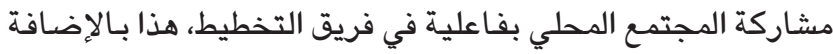

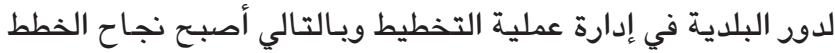

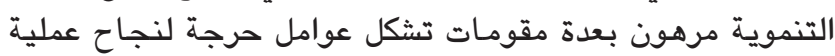

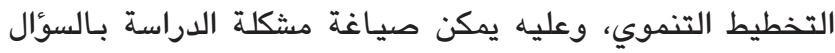

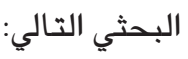

ما مستوى الصعويـات التي تواجهها الهيئات الهحلية في إعداد

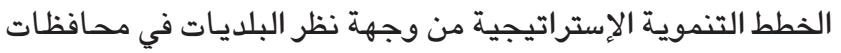
شمال الضفة الغربية وكيف يمكن التغلب على تلك الصعويـات.

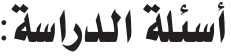

ما مستوى الصعويـات التي تواجهها الهيئات المحلية في إعداد الخطط التنموية الإستراتيجية من وجهة نظر البلديات في محافظات شمال الضفة الغريية؟

ما سبل التغلب على معيقات التخطيط التي تواجهها

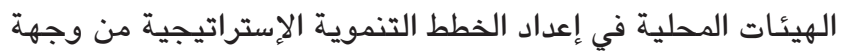

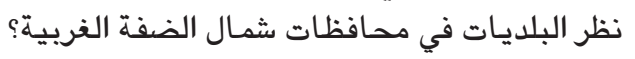
هل هناك فروق في الصعويات التي تواجهها الهيئات المحلية في إعداد الخطط التنموية الإستراتيجية تبعات فيعا للمتغيرات

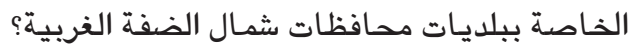

هل هناك علاقة بين عمر الهيئة المحلية ومستوى الصعويـات التي تواجهها الهيئات المحلية في إعداد الخطط التنموية التهرية الإستراتيجية الهوبات

\section{أهمية اللدراسة الهنة}

تكمن أهمية هذه الدراسة في الاهتمام بـالتخطيط التنموي

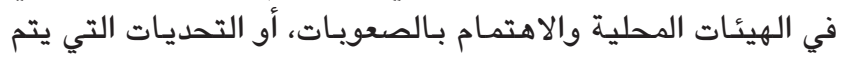




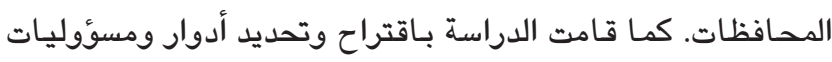

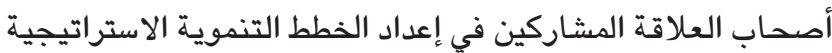

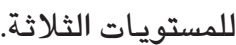

دراسة القيق، (2015)، هدفت هذه الدراسة إلى تتبع المشاركة

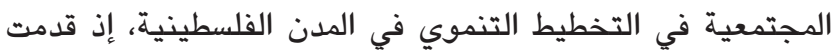

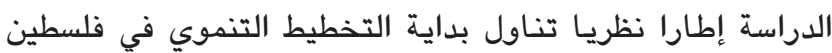

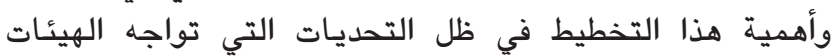

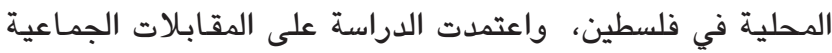

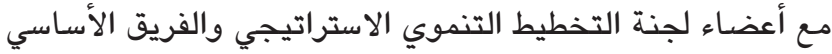

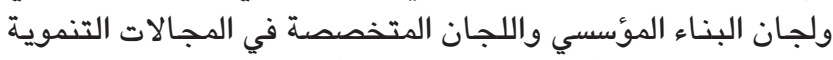
المختلفة واعتمدت أيضّا على مراجعة الأدبيات في جمع المعلومات العات التهات

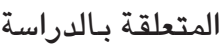

وخرجت الدراسة بمجموعة من الاستنتاجات أهمها أن

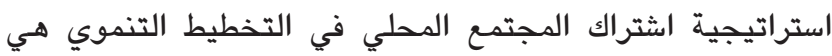

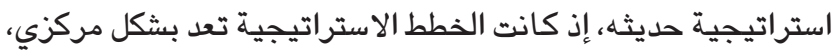

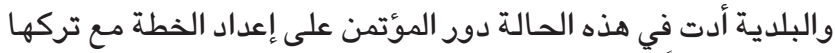

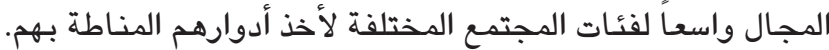

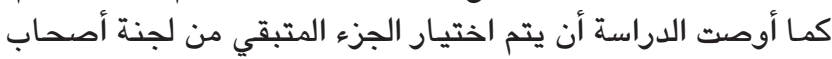

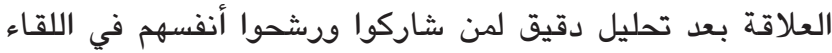

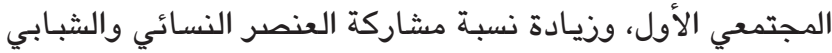
في اللجان، والتزام البلدية بتنفيذ المشاريع التنموية بنفس الآليات التيات

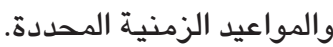

دراسة (Barcson 2015) هدفت إلى تناول الإصلاحات

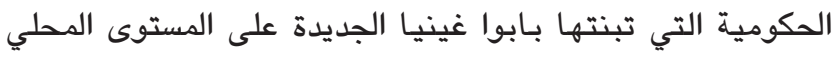

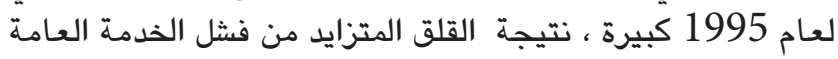

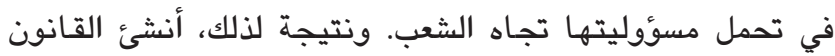

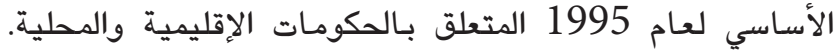

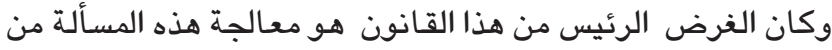

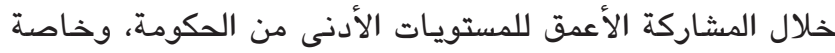

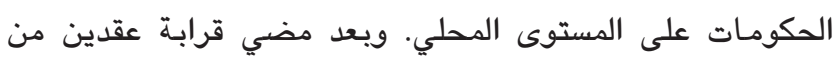

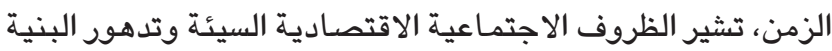

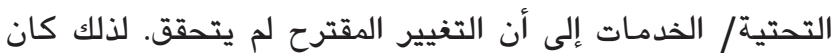

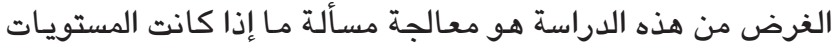

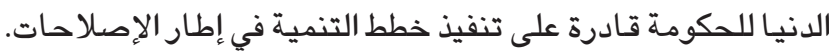

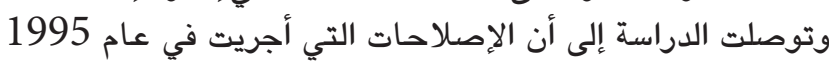

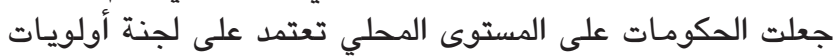

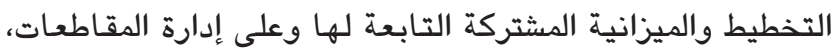

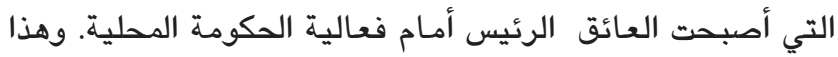

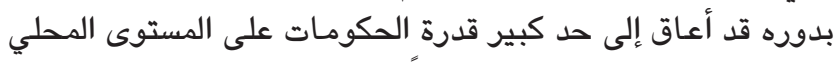

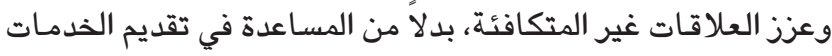

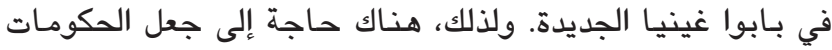
على المستوى المحلي أكثر فاعلية.

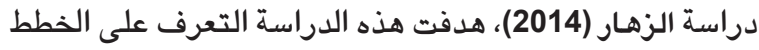

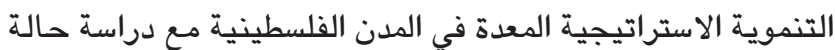

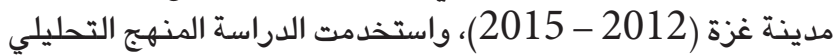

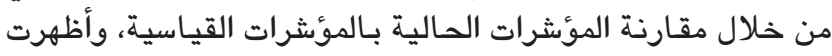

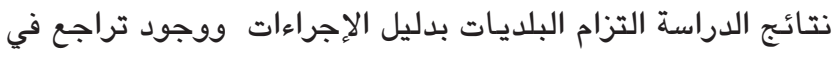

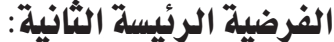

لا توجد فروق ذات دلالة إحصائية عند مستوى الدلالة

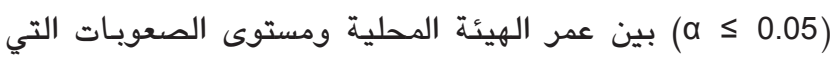

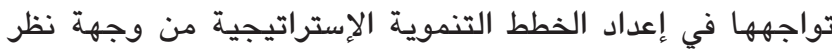
البلديات في محافظات شمال الضفة الغربية.

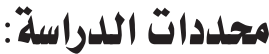

1 1. محدّد مكاني: محافظات شمال الضفة الغربية.

2. 1. محدّد زماني: سيتم تطبيق هذه الدراسة في عام (2018

\section{الدراسات السابقة}

تناولت العديد من الدراسات التخطيط التنموي في الهيئات

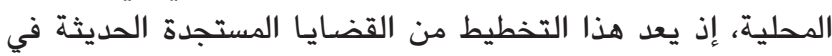

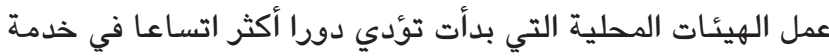

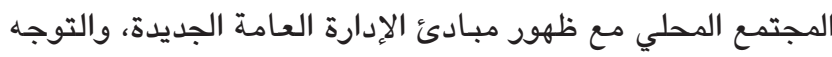

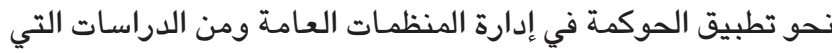
تناولت التخطيط الاستراتيجي التنموي في الهيئات الدحلية:

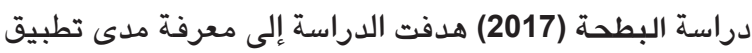

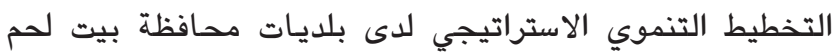

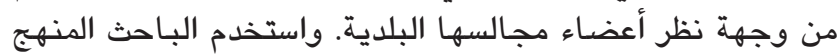

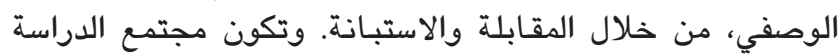

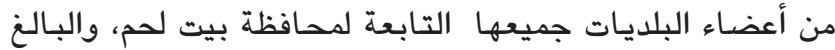

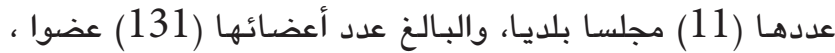

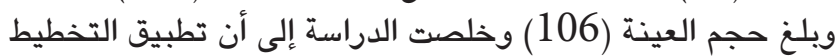

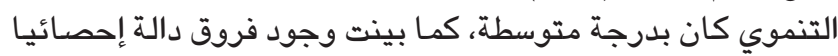

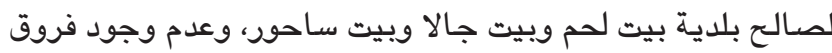
لمتغيرات الجنس والمستوى التعليمي وسنوات الخبرة. دراسة الخياط (2015) هدفت هذه الدراسة إلى إعداد نموذج الإنجات

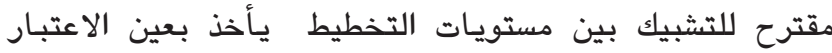
التكامل والتنسيق بينها. اعتمدت الدراسة على المبادئ الأساسية الأنيات

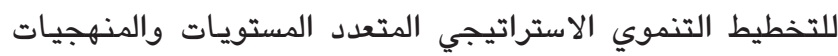
المتبعة للتكامل والتنسيق بين المستويات المختحتلفة التحن من التخطيط.

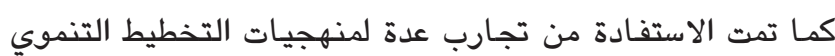

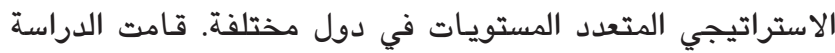

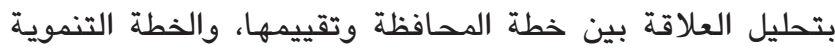

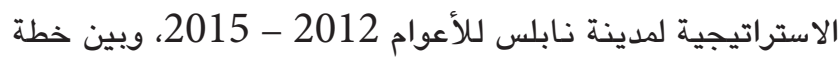

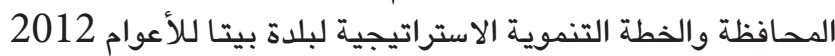

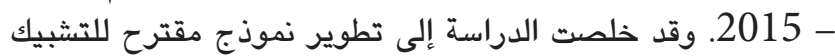

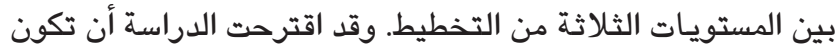

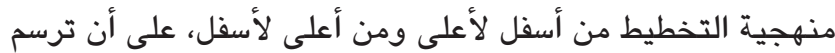

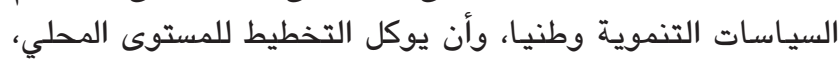

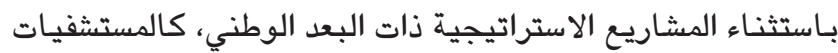

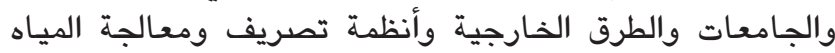

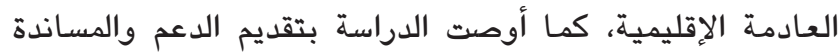
للبلديات والمجالس المحلية المشتركة في إعداد خططها العادية المحلية،

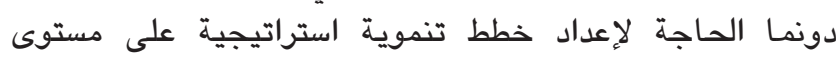


اكتمـالها. لم يستفد المجتمع من المشروع ولم تتحقق خطط البلديات. دراسة حامد (2009) هدفت التعرف إلى واتع الهيئات الهحلية

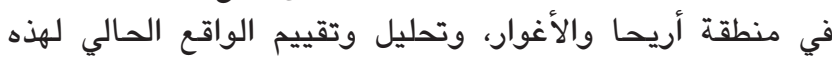
الهيئات. ولتحقيق هدف الدراسة استخدم المنهج المسحي الوصفي والحي

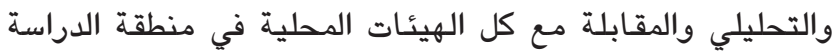

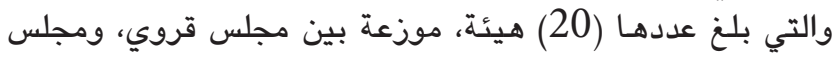

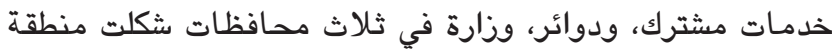

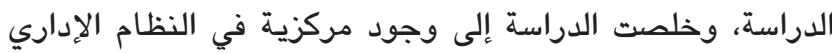

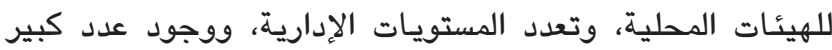

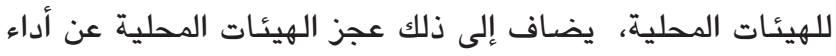

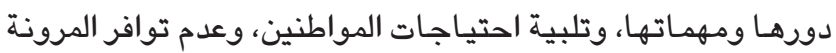

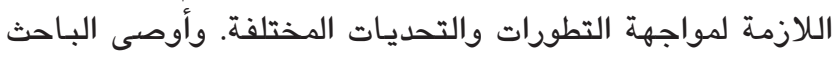

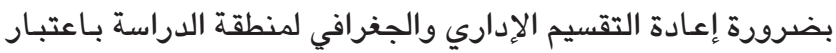

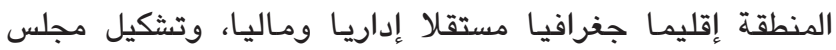

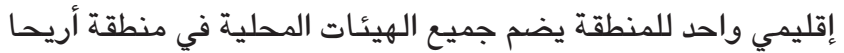

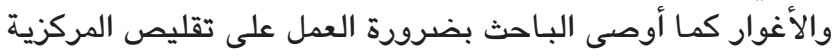

الإدارية للسلطة المركزية.

\section{دراسة قدومي (2008) هدفت الدراسة استكشاف لدور}

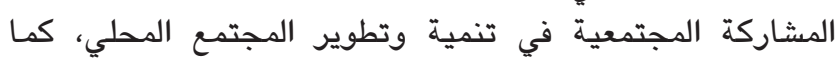
حاولت الكثف عن العلاقة ما بين المشاركة المجتمعية ومستواهـا

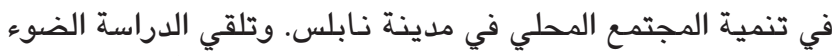

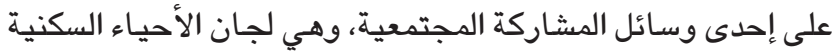

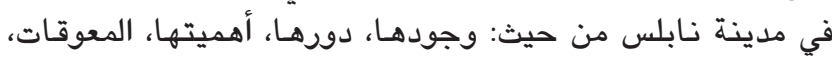

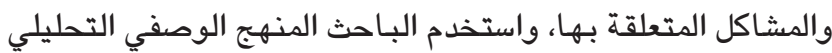

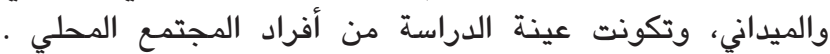

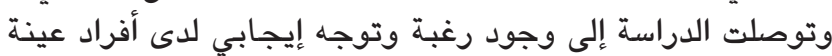

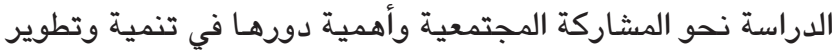

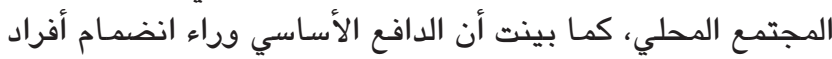

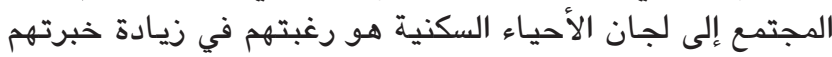

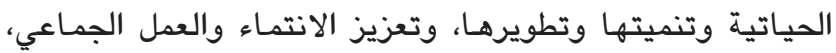

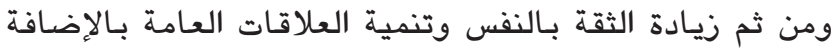

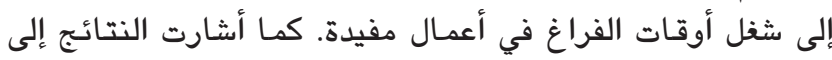

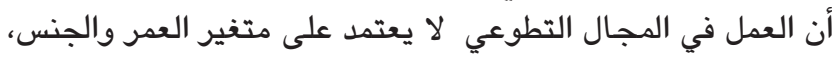

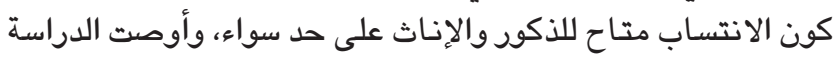

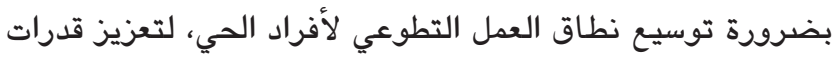

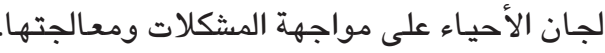

دراسة الههوز (2008) بعنوان اتجاهـات التخطيط التنموي

لمدينة نابلس في ضوء الإستراتيجية المقترحة لتنمية وتطوير

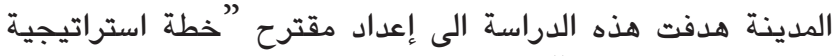

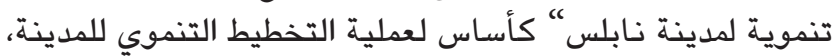

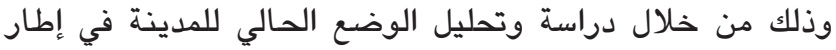

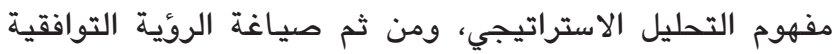

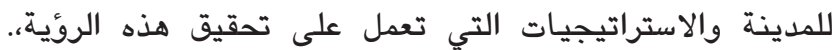

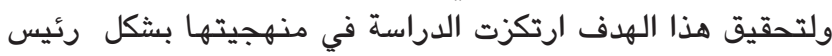

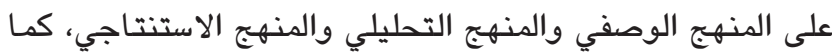

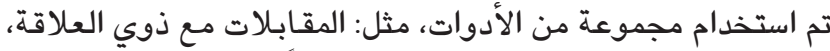

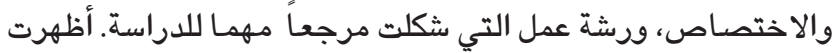

المشاركة المجتمعية، وأن تنفيذ الخطط يسير بخطى بطيئة، وأن أهم المشاكل التي يواجهها التخطيط ضعف التمويل اللازم للمشاريع.

وقدمت الدراسة عددا من التوصيات كان أبرزهـا حث بـ الاهن

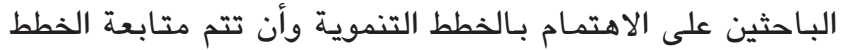
التنموية وتقييم مدى نجاحها.

دراسة (Dyadik 2014) التي هدفت التعرف إلى التحديات

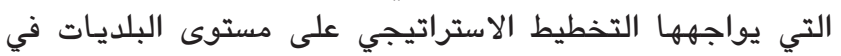

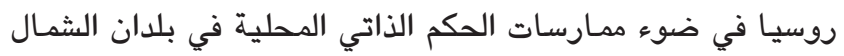

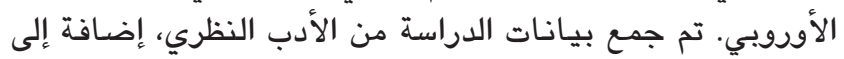

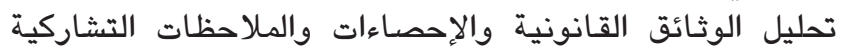

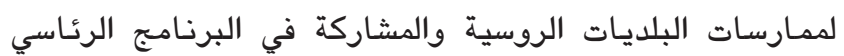

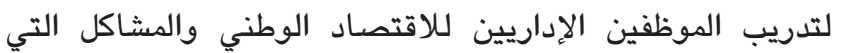
تواجهها البلديات الروسية في وضع وتنفين الإدين الخطط الاستراتيجية

الناجحة لتطويرهـا.

وكثفت الدراسة أن هناك مجموعتين رئيستين من المشاكل:

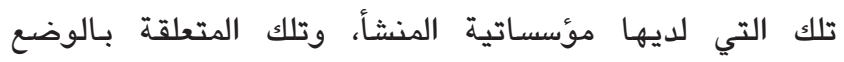
الاقتصادي في البلديات في روسيا. تبين أن المؤسسات الرسمية على المستوى الوطني تعمل على لى لى

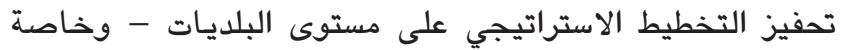
في الأنظمة والقوانين التي تفتقر إليها. وينطبق الثئ الثيء نفسيه

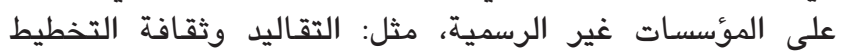

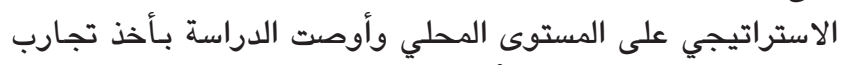

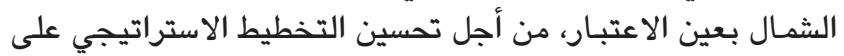
مستوى البلديات في روسيا.

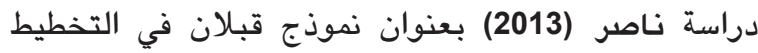

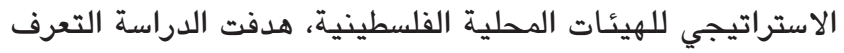

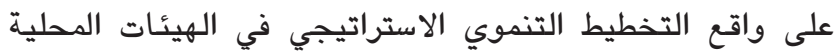

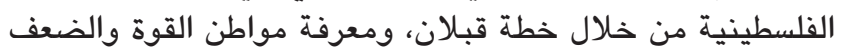

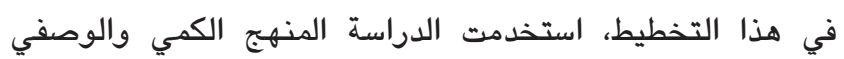

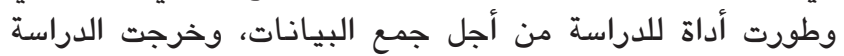

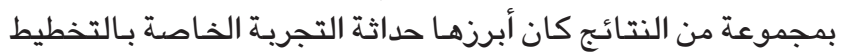
الاستراتجي التنموي وعدم اكتمال جميع مراحل التخطيط التنموي

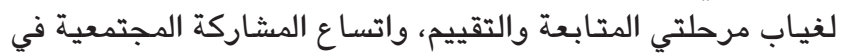
التخطيط.

وقدمت الدراسة عددا من التوصيات، كان أبرزهـا تبني منهج

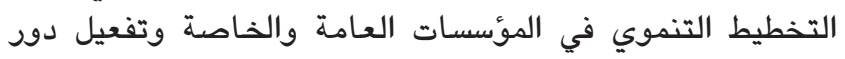

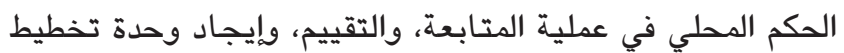
تنموي في كل وحدة محلية. دراسة (Machaka 2012) هدفت الدراسة التعرف على التي

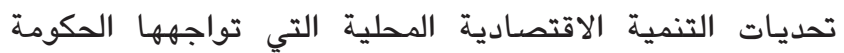

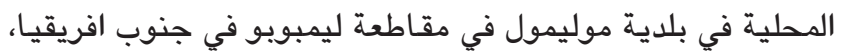

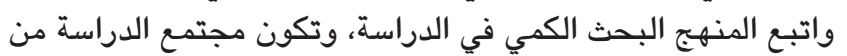

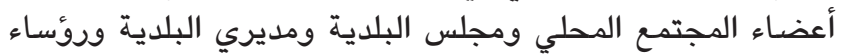

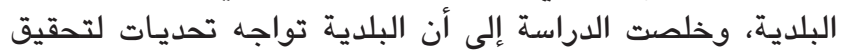

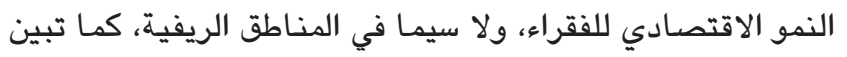

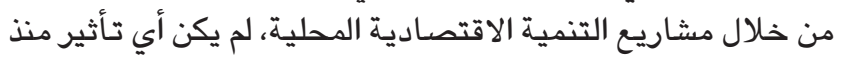


التنموي لأول مرة في قانون تخطيط المدن في بريطانيا عام

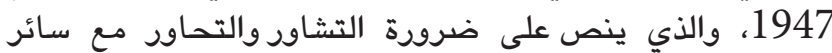

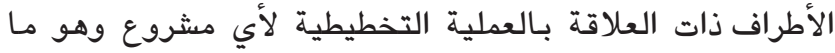

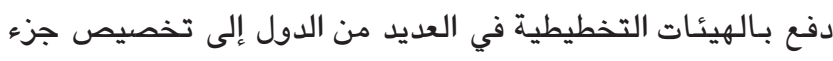

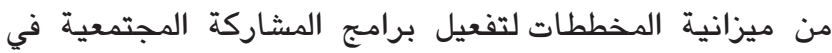
التخطيط، (القيق،2015،وسئ 131) وقد تناولت العديد من الأدبيات

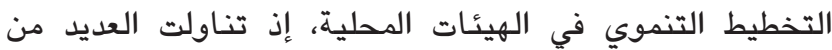

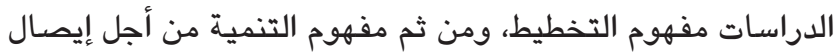

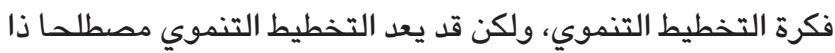

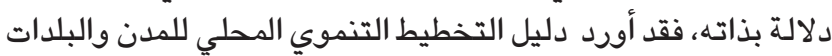

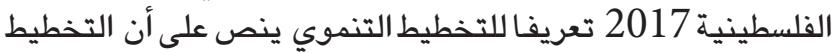

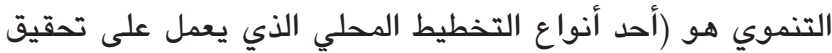

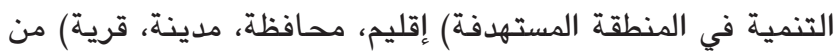

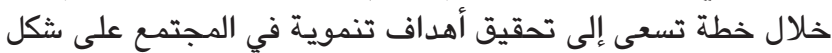

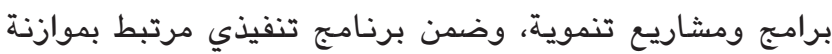

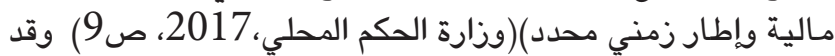

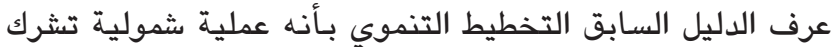

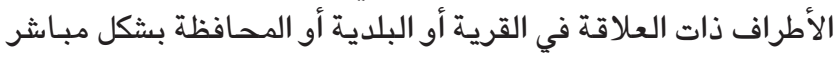

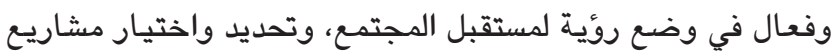

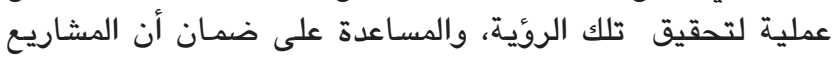

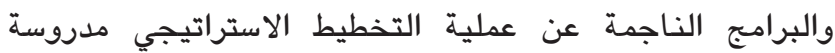
بعنايـة، ومنطقية، وتمثل أفضل استخدام للموارد، والمساعدة الماتية

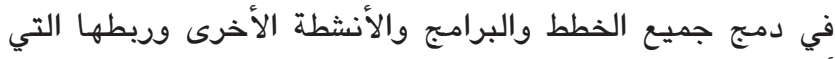

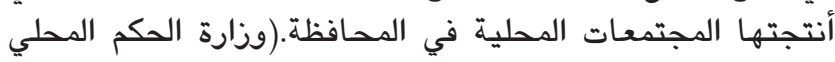

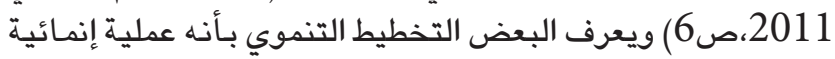
تشمل إجراء ثلاث عمليات فنية أساسية هي: وضع الهيع أهداف منسقة،

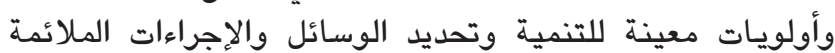

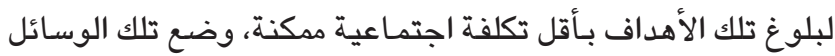

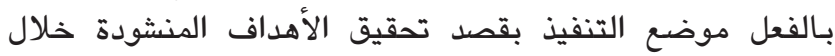

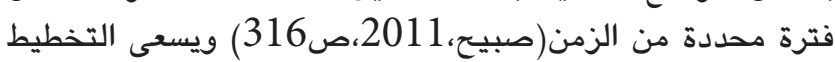

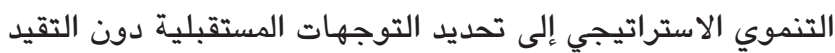

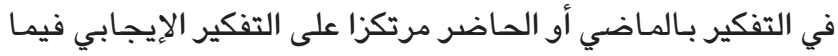

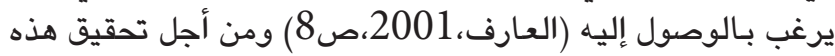

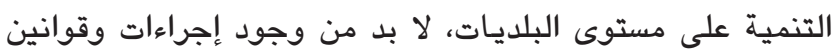

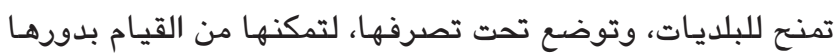

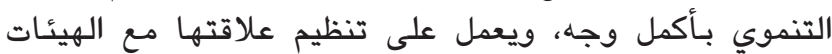

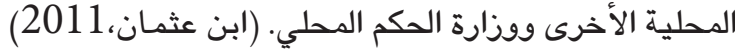

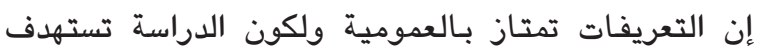

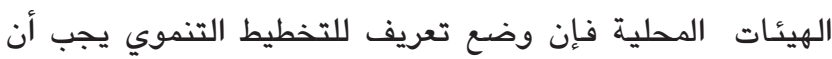

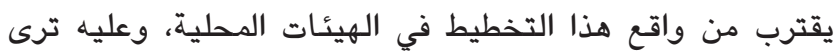

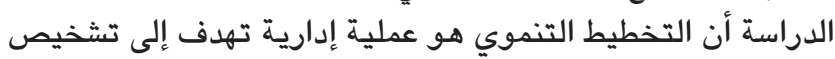

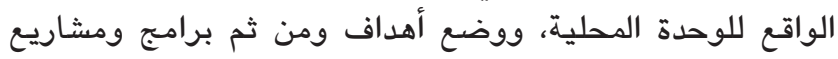

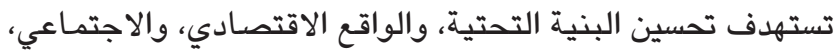

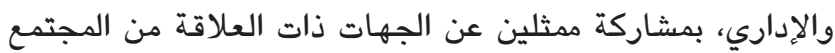

المحلي الذي تعمل به الوحدة الدحلية لمدة زمنية معينة.

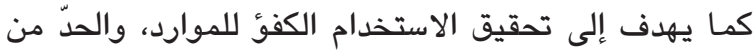

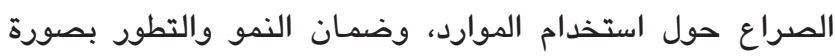

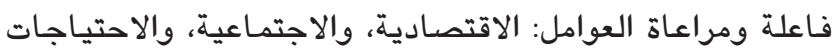

نتائج الدراسة أن المدينة تتمتع بعدد من الفرص والإمكانيات

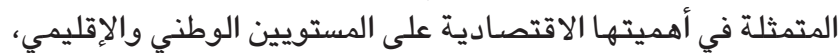
وأيضاً أهميتها السياحية والحضارية.

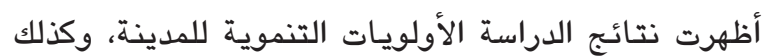

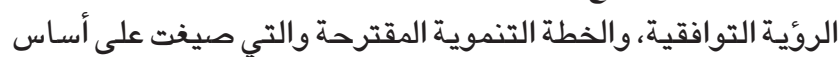

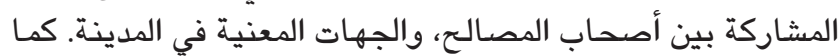

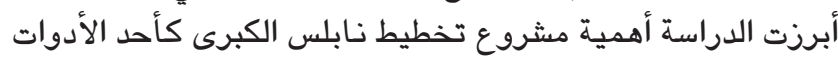

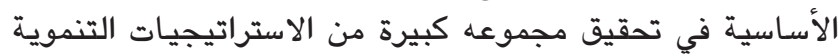

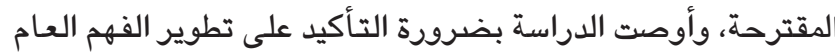

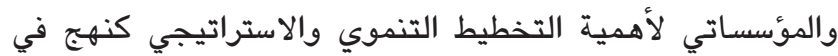
عملية التنمية الشاملة.

\section{التعقيب على الدراسات السابقة:}

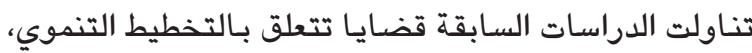
وأجمعت على أهمية التخطيط التنموي في إدارة الهيئات المحلية الدانية

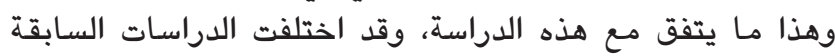

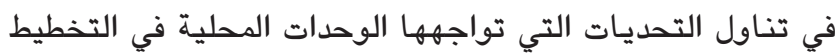

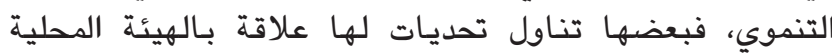
والوضع الاقتصادي في الدولة وركز بعضهات على على التحديات التنموية المتعلقة بمشكلة الفقر (Myadik,2014)، (Machaka,2012)

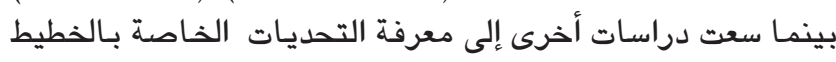

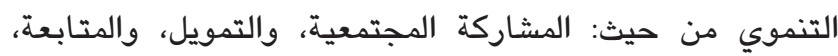

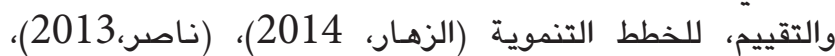
(القيق، 2015)، بينما اهتمت دراسات أخرى بالمشاركة المجتمعية، فقط (القدومي، 2008)، وتناولت بعض الدرات الدراسات السابقة مستويات التخطيط التنموي (2008)، (Barcson,2015)، وقداولت تميزت هذاته

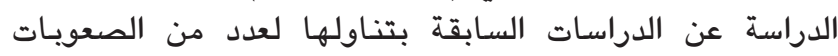

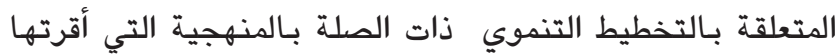

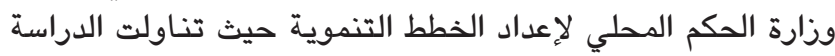

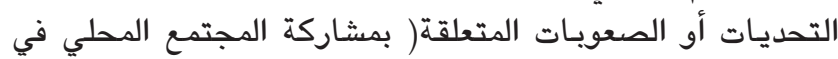

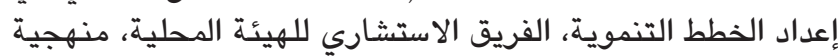

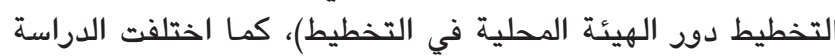

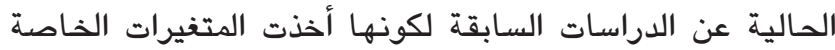

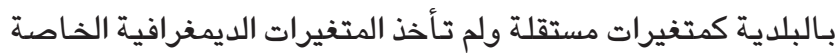

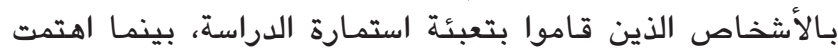

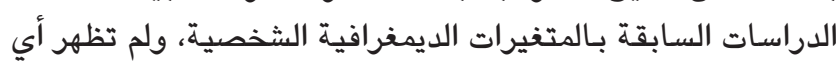
فروق في اختبارهـا.

\section{الإطار النظري}

تعريف التخطيط التنموي في الهيئات المحلية

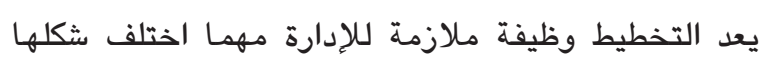

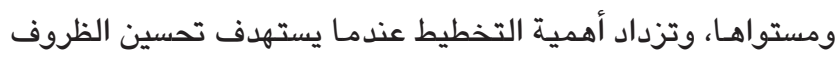

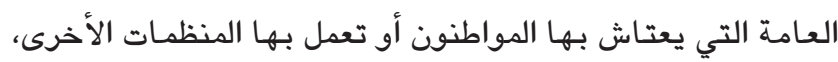

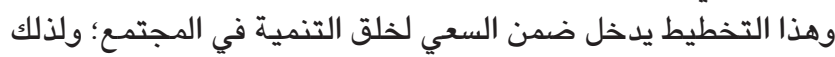

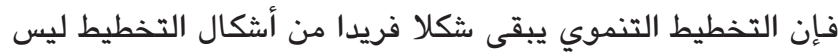

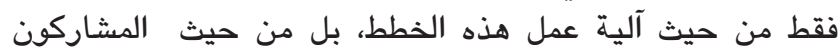

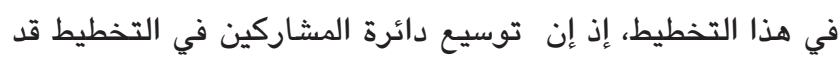
يفرض تحديات كثيرة على عملية التخطيط، وقد ظهر التخطيط التخيط التخطيط 
4. شمولية التشخيص والبعد الاستراتيجي: من حيث التركيز

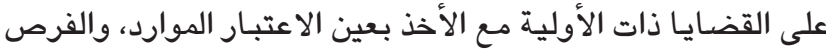

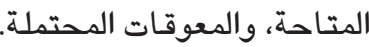

5. الكفاءة والفعالية: من حيث الارتقاء بـالمجتمع المحلي

لقيادة وتنسيق عملية التنمية المحلية

أما ما يتعلق بمراحل التخطيط التنموي، إذ يمر التخطيط

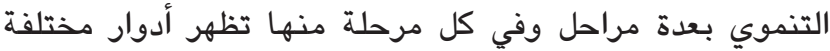

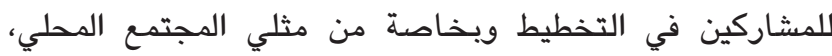

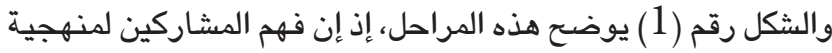

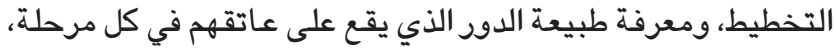

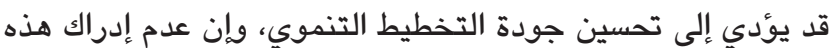

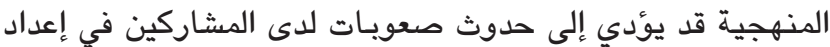
خطط تنموية تعكس احتياجات المجتمع الهحلي.
الهختلفة داخل المجتمع. (Government of Alberta.2018)

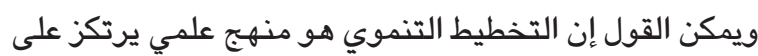
مبادئ الحوكمة والإدارة الرشيدة، ولذلك يتميز التخطيط التنموي

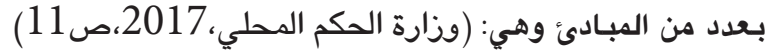

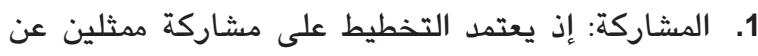
المجتمع المحلي في جميع المراحل التي يمر بها التخطيط. 2. الشفافية والمساءلة: وفيها يتم مشاركة جميع مدثلي المجتمع المحلي في الاطلاع على الوثائق، وتحمل المسؤولية في كل

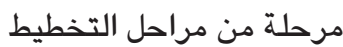
3. التكاملية: من حيث التطرق للقضايا الاجتماعية

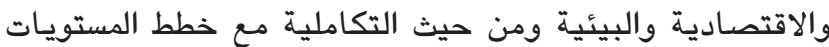
الادارية المختلفة، والتخطيط العمراني/الهيكلي، وموازنات الهينية الهينات

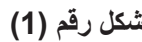

مراحل التظطيط التنموي الاستراتيجي وفق دليل التظطيط التنموي

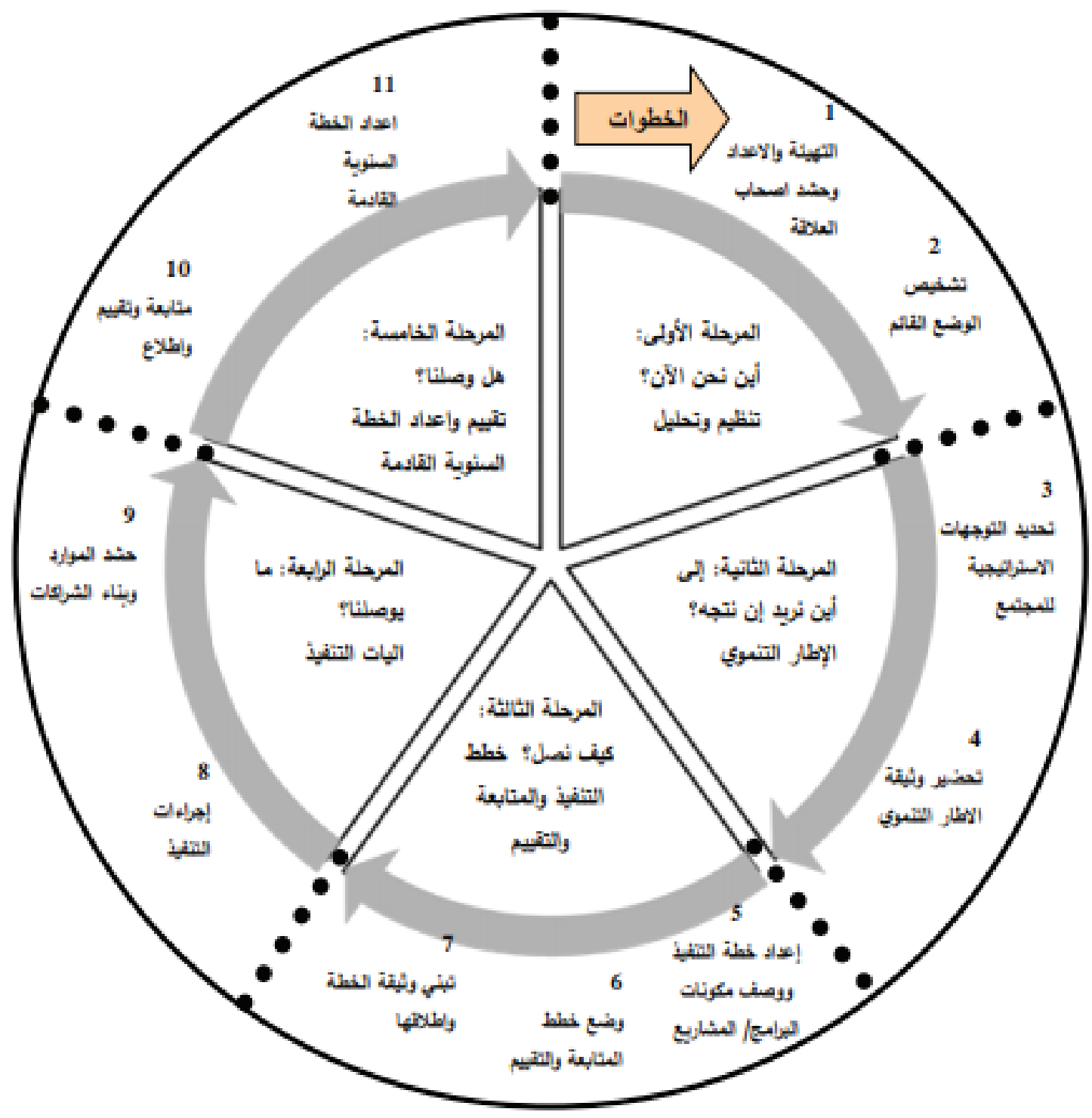

المصدر: وزارة الحكم المحلي,(2017),دليل التخطيط التنموي ,رام الله ,فلسطين. 
التهيئة والإعداد، وتوضيح الأدوار وحشد أصحاب العلاقة من خلال

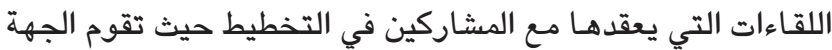

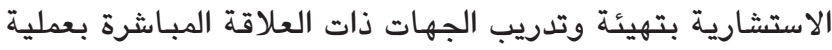

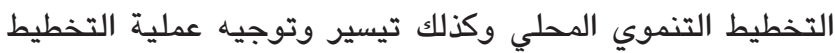

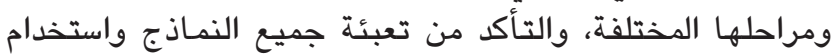

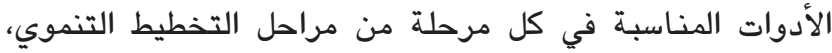

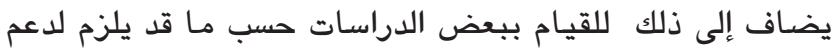

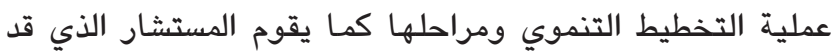

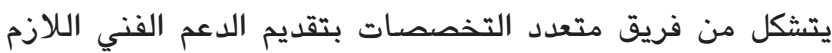
لمأسسة عملية التخطيط وتنفيذ مخرجاتها والتهات والتأكد من واقعيتها.

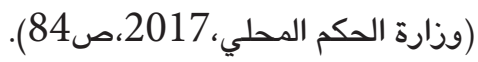

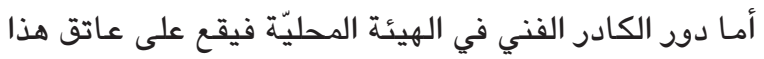

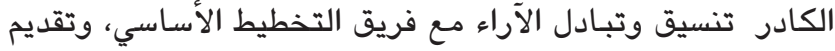

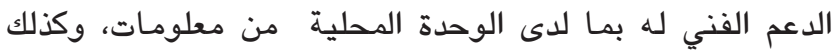

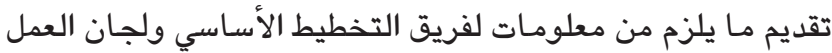

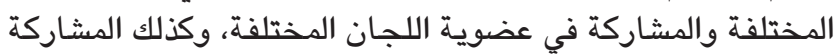

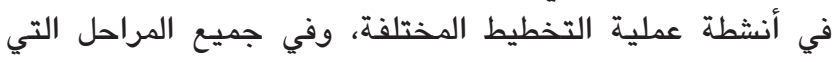

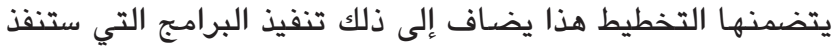

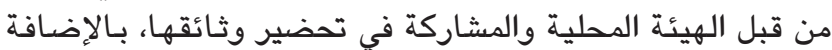

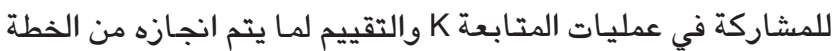

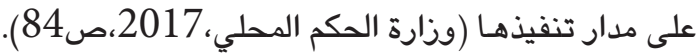

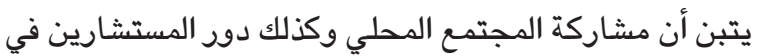

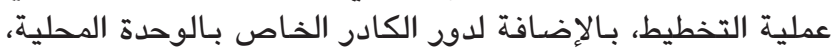

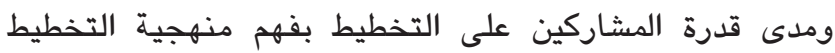

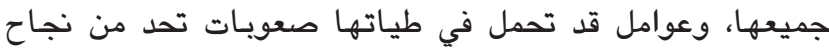

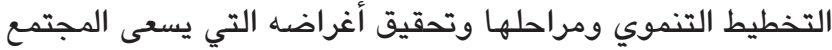
الدحلي والوحدة الدحلية لتحقيقها.

\section{إجراءات الدراسة ومنهجها:}

منهج اللدراسة

وظف الباحثون المنهج الوصفي التحليلي لتحقيق أهداف الدراسة، حيث تم تصنيف البيانات التي جمعت من المبندي التحوثين،

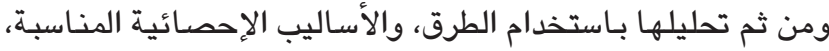
ومناقشتها، وربطها بالإطار النظري، والدراسات السابقة.

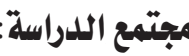

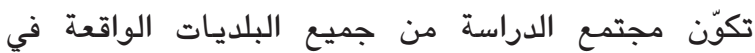
محافظات شمال الضفة الغربية، والبالغ عددها حوالية حوالي (45) بلدية،

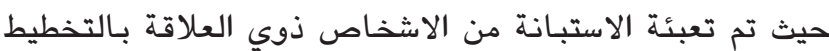

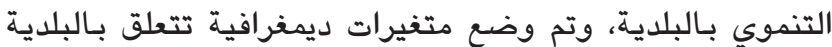
وليس بالأشخاص الذين قاموا بتعبئة الاستبانة.

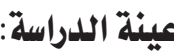

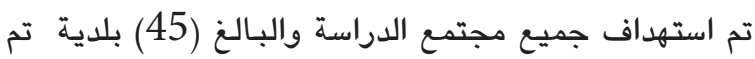

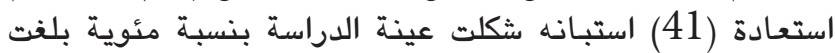
(91 \%)، وشملت الأداة عدة متغيرات: الدحافظة التي تقع فئة فيها الهيئة الهحلية، تصنيف الهيئة المحلية، عدد سكان البلدة/الدئة الهينة،
إن المراحل التي يوضحها الشكل رقم (1) هي مراحل قائمة

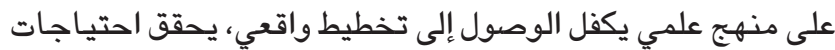

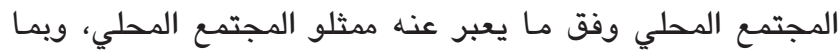

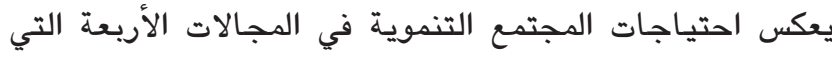

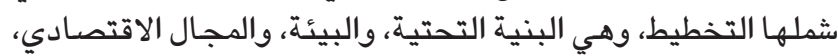
والدجال الاجتماعي، ومجال الحكم الرشيد.

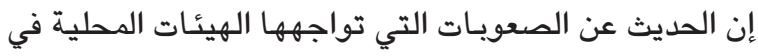

إعداد الخطة التنموية يتطلب الحديث عن الصعويات التبات التي تناولتها

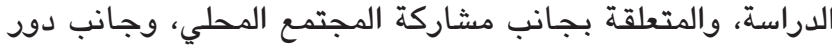

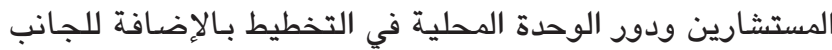

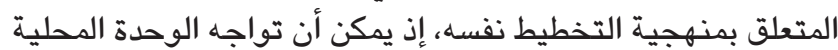

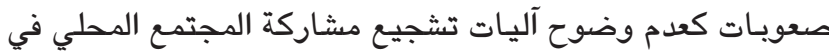
Shittu, A. I., \& Musbaudeen, الدول النامية على وجه الخصوح اليات تصوص

(A. M. 2016

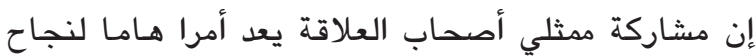

التخطيط التنموي، وينظر للمشاركة الهجتمعية على أن لها ألهاتئيرا

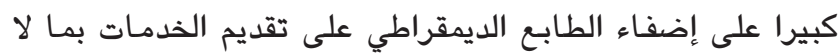

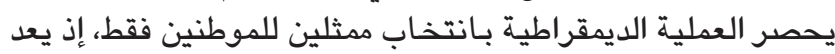

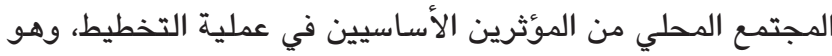

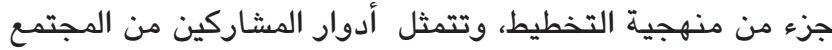

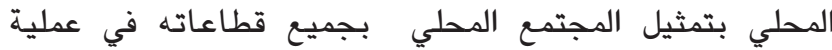
التخطيط التنموي والمشاركة في أنشطة، عملية التخطيط المختلفة (Thanyani .S \& Maloka.C,2014)

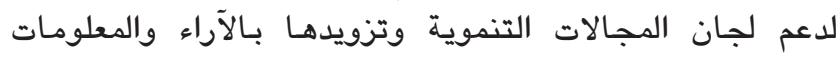

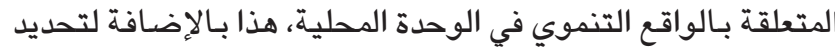

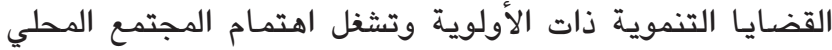

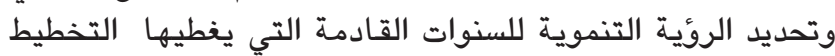

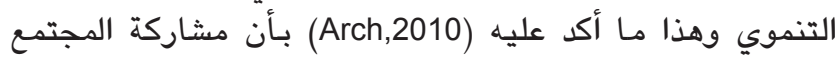

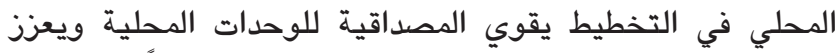

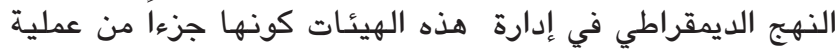

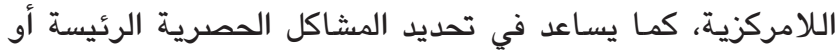
تحديد الأولويات كما يراهـا المجتمع المحلي. تصدي الهاكل الديات

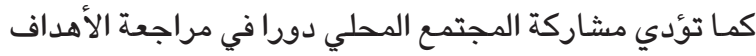

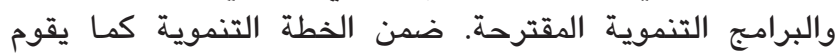

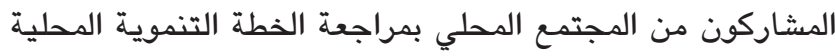

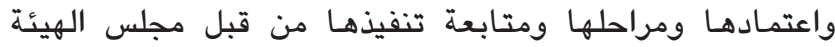

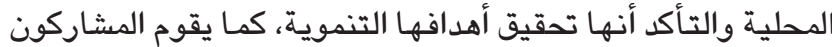

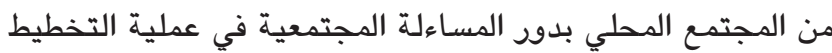

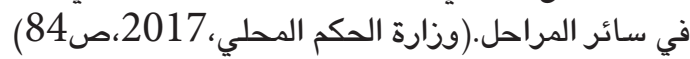

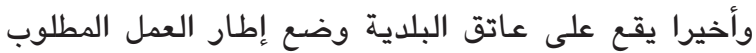

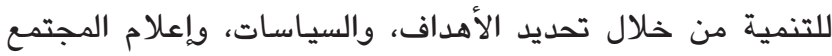

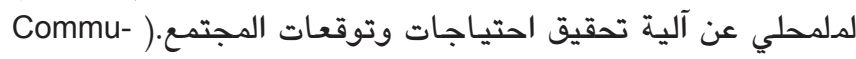
(nity Planning Branch, 2011

أما دور الاستشاري بشكل عام، فقد سمحت أنظمة الحكم

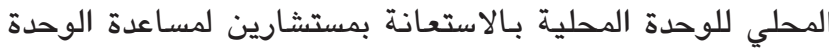

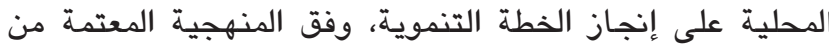
الوزارة، ويتضمن دور المستشار تقديم الدعم الفني خلال مرحلة الفية العتمة 


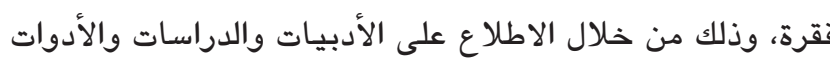

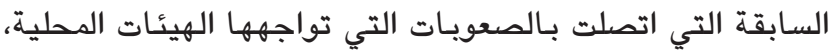
تم بعد ذلك التحقق من صدق وثبات الأداة حسب الآتي:

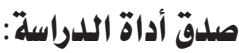

للتحقق من صدق أداة الدراسة بصورتها المبدئية اتبعت

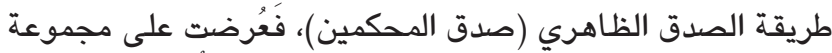

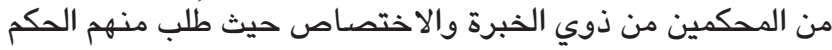

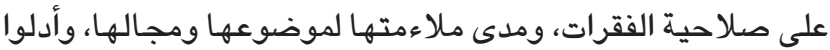

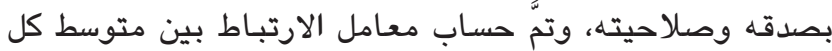

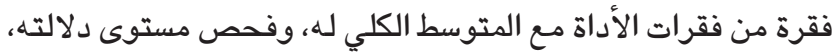

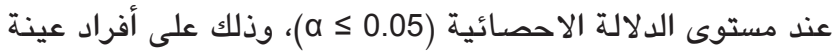

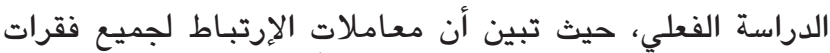

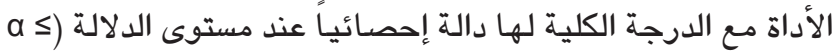

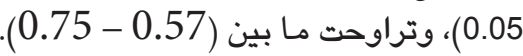

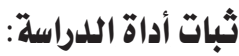

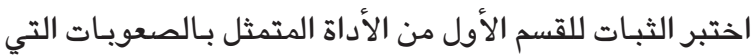

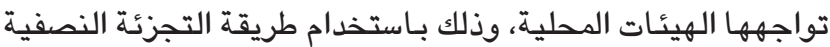

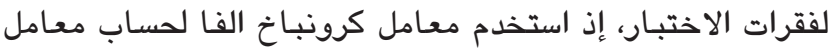

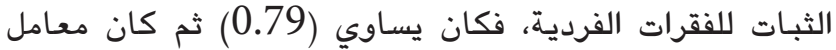
كرونباخ ألفا للفقرات الزوجية (0.71)، وبعد ذلان ذلكان حسب معان معامل

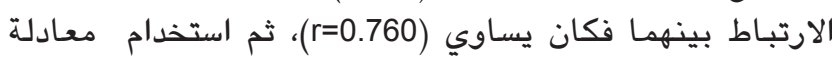

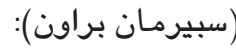

معامل الثبات (Reliability Coefficient) $=\frac{2 r}{1+r}$

حيث(r) هو معامل الارتباط بين الفقرات الفردية والزوجية.

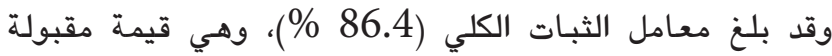
لأغراض الدراسة، وتعطي دلالة على أن الأداة تتمتع بدرجة مرتفعة قدية

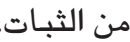

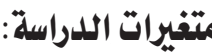

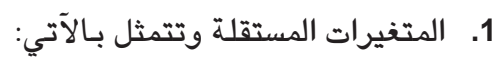

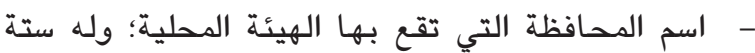
مستويات هي: (جنين ، طوياس ، طولكرم ، نابلس ، سلفيت ، قلقيلية). - تصنيف الهيئة المحلية؛ ولها ثلاثة مستويات هي:

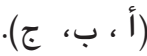

- عدد سكان البلدة/الدينة؛ وله أربعة مستويات هي: (أقل

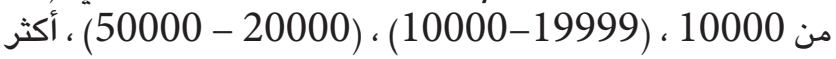

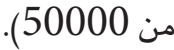

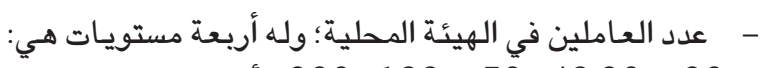
(أقل من 20، - 490 ، 50 - 50 - 199 ، 200 فأكثر).

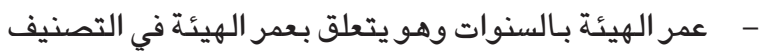

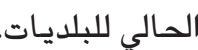

تعدد العاملين في الهيئة المحلية، والجدول الآتي يوضّح كيفية

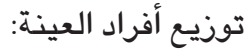

جدول (1)

توزيع أفراد العينة بحسب اسم الهيئة المحلية، تصنيف الهيئة المحلية، عدد سكان البلدة/ المدينة، عدد العاملين في الهيئة المحلية

\begin{tabular}{|c|c|c|c|}
\hline النسبة المئويـة & 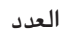 & مستويـات المتغير & المتغير \\
\hline$\% 34.1$ & 14 & جنين & \\
\hline$\% 7.3$ & 3 & طوياس & \\
\hline$\% 17.1$ & 7 & طولكرم & \\
\hline$\% 19.5$ & 8 & نابلس & اسم المحافظة \\
\hline$\% 9.8$ & 4 & سلفيت & \\
\hline$\% 12.2$ & 5 & قلقيلية & \\
\hline$\% 14.6$ & 6 & أ & \\
\hline$\% 26.8$ & 11 & ب & تصنيف الهيئة المحلية \\
\hline $58.5 \%$ & 24 & ج & \\
\hline $63.4 \%$ & 26 & أقل من 10000 & \\
\hline $17.1 \%$ & 7 & (19999 10000-) & عدد سكان البلدة/ \\
\hline $12.2 \%$ & 5 & $(50000-20000)$ & المدينة \\
\hline $7.3 \%$ & 3 & أكثر من 50000 & \\
\hline $61.0 \%$ & 25 & أقل من 20 & \\
\hline $17.1 \%$ & 7 & $4920-$ & عدد العاملين في الهيئة \\
\hline $14.6 \%$ & 6 & $199-50$ & المحلية \\
\hline $7.3 \%$ & 3 & 200 فأكثر & \\
\hline
\end{tabular}

فيما يتعلق بتصنيف الهيئات الهحلية فقد تم تصيف البلديات

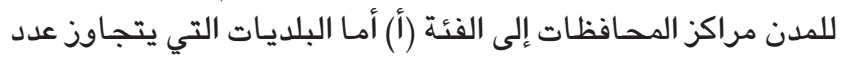

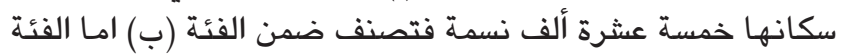

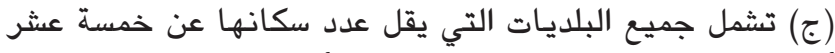

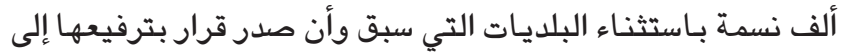
الفئة (ب).( وزارة الحكم الدحلي، 2016)

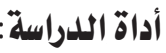

بهدف قياس مستوى الصعويات التي تواجهها الهيئات

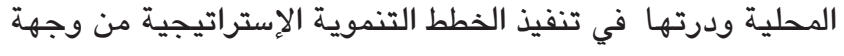

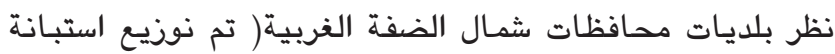

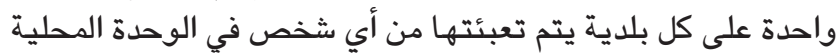

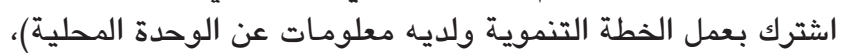

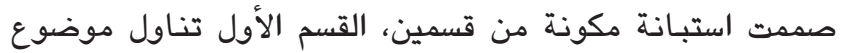

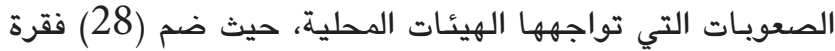
موزعة على أريعة أبعاد: (المشكلات المتعلقة بالفريقات الفيقات الاستشاري

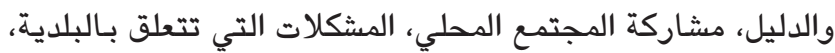

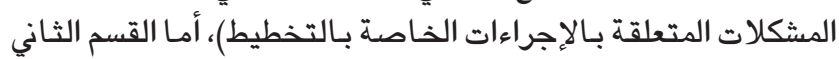
فتناول موضوع سبل التغلب على معيقات التخطيط، وضم (11) 


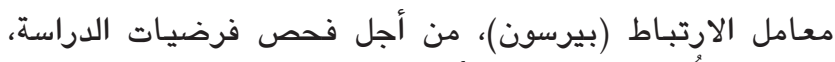

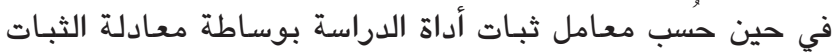

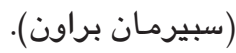

\section{عرض نتائج الدراسة ومناقشتها}

القسم الأول: النتائج المتعلقة بأسئلة الدراسة:

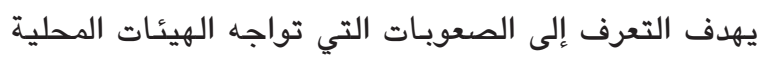

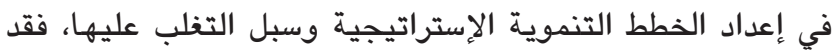

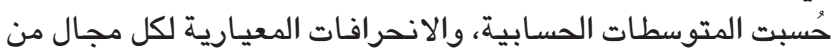

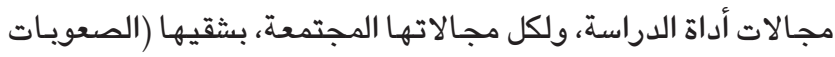

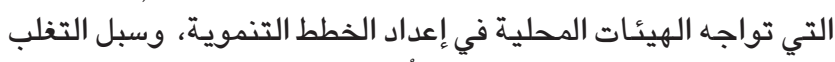
عليها) ولتسهيل عرض النتائج اعتُمد التوزيع الآتي:

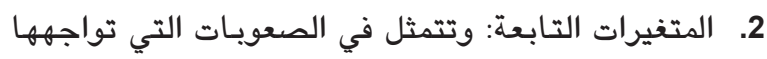

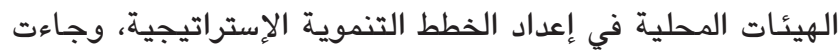

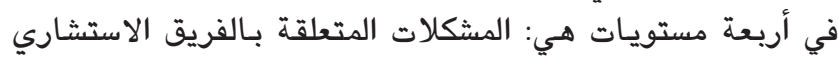

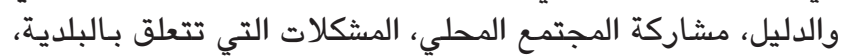
المشكلات المتعلقة بالإجراءات الخاصة بالتشعيط.

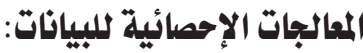

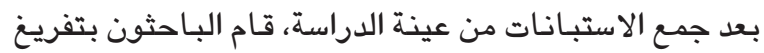

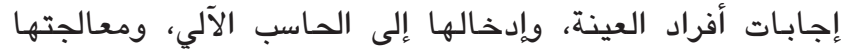

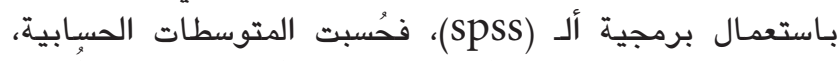
والانحرافات المعيارية؛ من أجل الإجابة عن أسئلة الدراسة، وأُجري الجرية

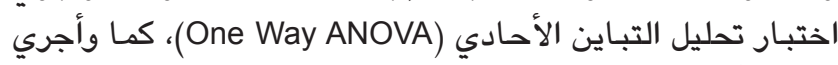
اختبار أقل فرق دال إحصائيا للمقارنات البعدية (LSD)، وحُسب التحري

\begin{tabular}{|c|c|c|c|c|c|}
\hline منخفضة جداً & منخفضة & متوسطة & كبيرة & كبيرة جداً & درجات الاستجابة \\
\hline 1 & 2 & 3 & 4 & 5 & درجة الاستجابة \\
\hline $1.80-1$ & $2.60-1.81$ & $3.40-2.61$ & $4.20-3.41$ & $5.0-4.21$ & المتوسط الحسابي \\
\hline
\end{tabular}

يتضح من الجدول (2) أن مستوى الصعوبـات التي تواجهها

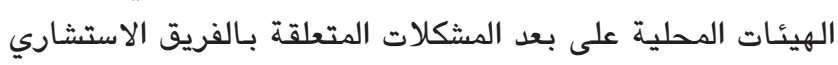

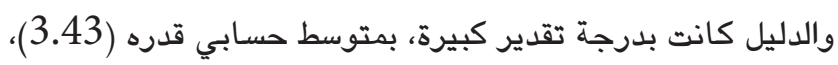

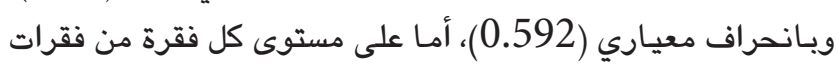

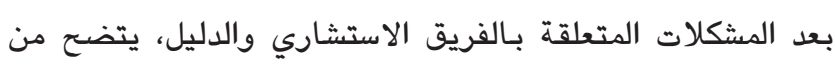

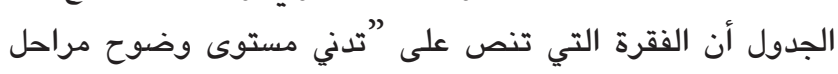

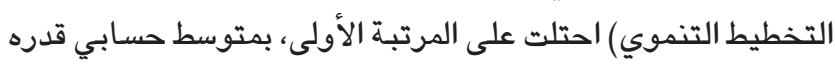

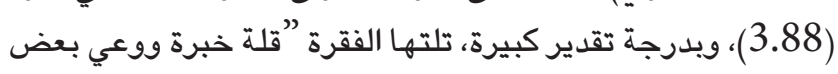

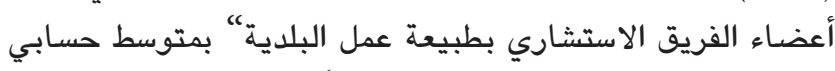

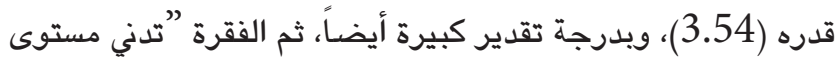

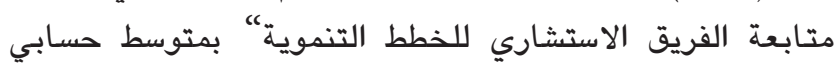
قدره (3.51)، ويدرجة تقدير كبيرة، ثم الفقرة "الالتزام بالدليل

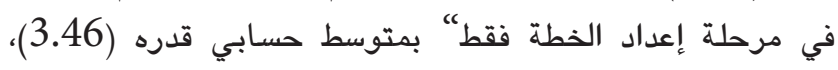

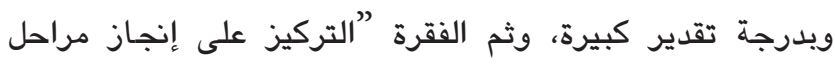

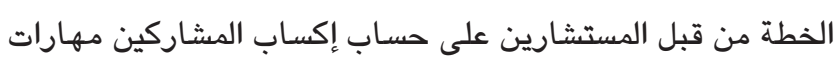

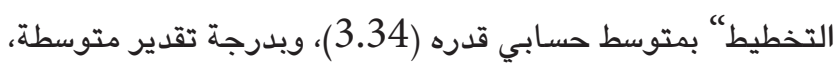

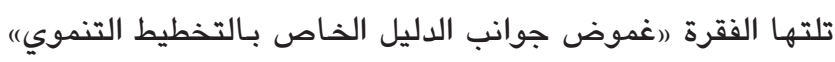

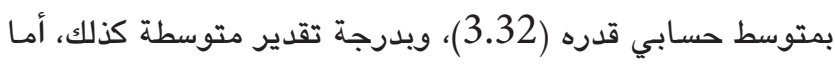

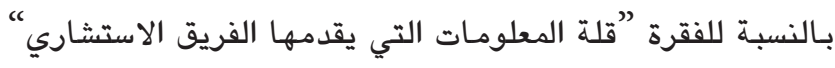

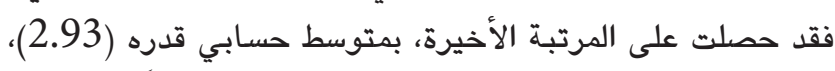

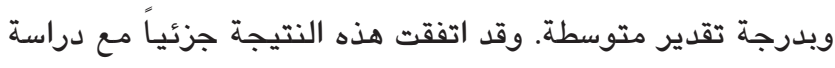

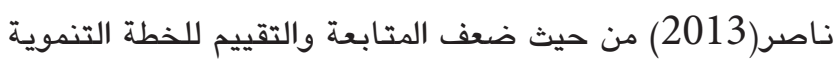

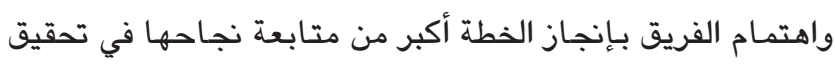

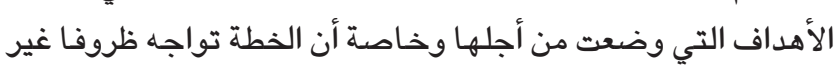
متوقعة أثناء إعدادها.
1. النتائج المتعلقة بالسؤال الأول (مستوى الصعويات التي الهئي

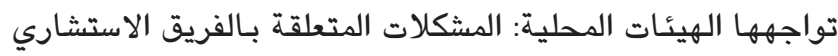

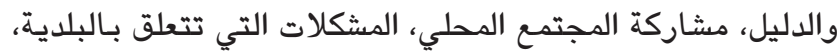
المشكلات المتعلقة بالإجراءات الخاصة التهاء التخطيط):

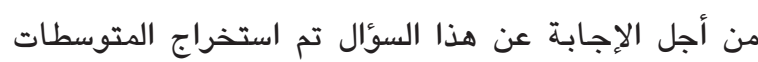

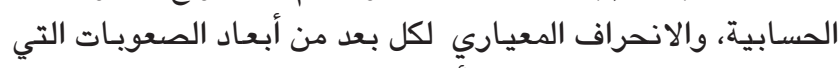
تواجهها الهيئات المحلية، وللأبعاد مجتمعة، وفيما يلي بيان ذلكان الكيات الكي

\section{جدول (2)}

\begin{tabular}{|c|c|c|c|}
\hline الدرجة & المعياري & الحسابي المتي & المشكلات المتعلقة بالفريق \\
\hline متوسطة & 1.149 & 2.93 & قلاستشاري الدعلومات التي يقدمها الفريق \\
\hline كبيرة & 0.557 & 3.88 & تدني مستوى وضوح مراحل \\
\hline متوسطة & 1.254 & 3.32 & بالتخطيط التنموضي الدوليل الخاص \\
\hline كبيرة & 1.002 & 3.54 & الفلدية الاستشاري بطبيعة عمل \\
\hline كبيرة & 1.185 & 3.46 & 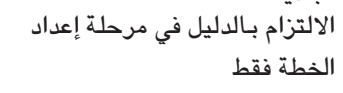 \\
\hline كبيرة & 1.098 & 3.51 & تلدني مستوى متابعة الفريق \\
\hline متوسطة & 1.087 & 3.34 & 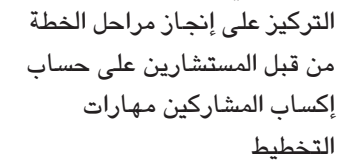 \\
\hline كبيرة & 0.592 & 3.43 & 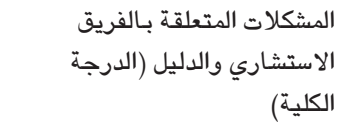 \\
\hline
\end{tabular}


اللجان الخـاصة من أفراد المجتمع المحلي” بمتوسط حسابي قدره

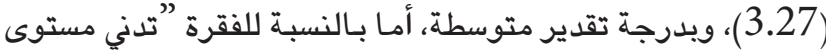

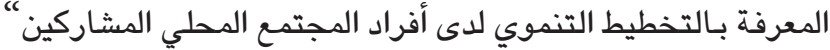
فقد حصلت على المرتبة الأخيرة، بمتوسط حسابي قدره الدئ (3.24)،

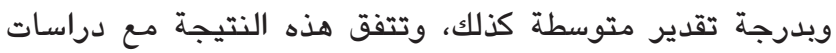

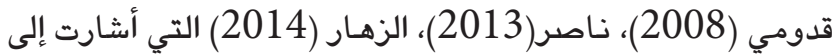
انخفاض المشاركة المجتمعية في إعداد الخطط التنموية، وقدا لاهدير يعود

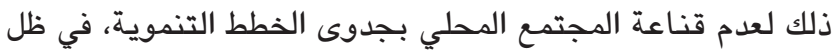

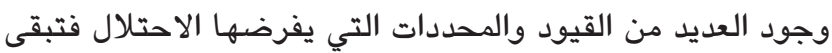
الخطط رهينة الموافقات والاعتبارات الاحتلالية.

جدول (4):

\begin{tabular}{|c|c|c|c|c|}
\hline 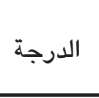 & المعياري - المراف & الحسابي & المشكلات التي تتعلق بالبلدية & 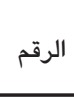 \\
\hline كبيرة & 1.223 & 3.83 & تلدة الدعم المقدم من البلدية التخدية & \\
\hline كبيرة & 0.949 & 3.44 & 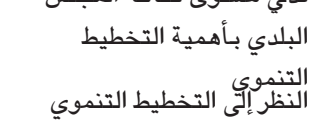 & \\
\hline كبيرة & 1.105 & 3.68 & في ظرتين شكلي يصعب تحقيقات التي تواجه & \\
\hline متوسطة & 1.078 & 3.29 & 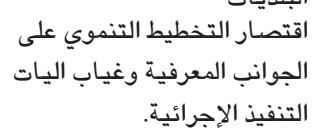 & \\
\hline كبيرة & 0.972 & 3.61 & 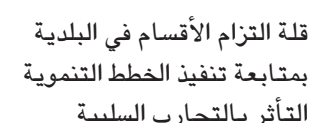 & \\
\hline كبيرة & 0.915 & 3.63 & التنمويقة للبلدياركة الأقسام في التخطيط & \\
\hline كبيرة & 0.954 & 3.88 & التندوية في البلدية بالخطة & \\
\hline كبيرة & 0.563 & 3.62 & 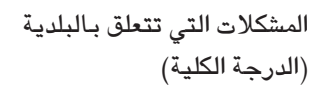 & \\
\hline
\end{tabular}

يتضح من الجدول (4) أن مستوى الصعويـات التي تواجهها

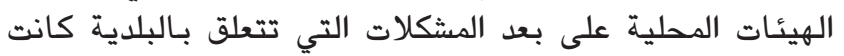
بدرجة تقدير كبيرة، بمتوسط حسابي قدره (3.62)، ويـانحراف

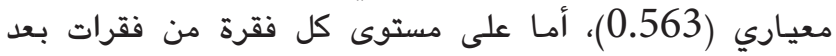

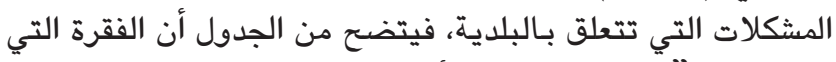

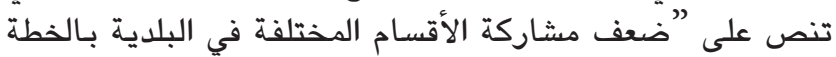

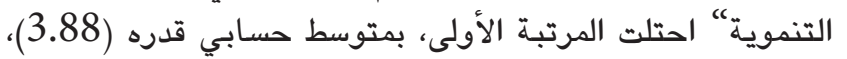

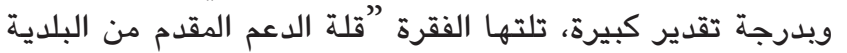

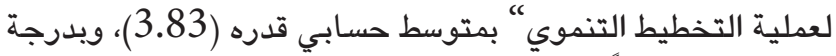
تقدير كبيرة أيضـاً، ثم الفقرة ”النظر إلى التخطيط التنموي كروتين

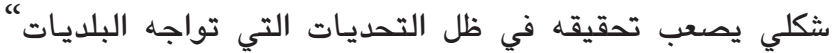
بمتوسط حسابي قدره (3.68)، ويدرجة تقدير كبيرة، ثم الفقرة

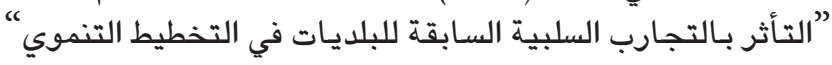
بمتوسط حسابي قدره (3.63)، ويدرجة تقدير كبيرة، تلتها الفقرة

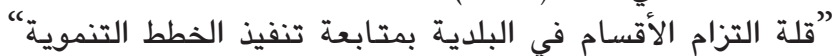

جذول (3)

المتوسطات الحسابية والاتحرافات المعيارية لمستوى الصعوبات التي تواجهها الهيئات المحلية على بعد مثاركة المجتمع المحلي المبات

\begin{tabular}{|c|c|c|c|c|}
\hline 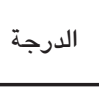 & الانحراف المعياري & الحسابي & مشاركة المجتمح المحلي & الرقم \\
\hline كبيرة & 1.097 & 3.44 & المعتوبة اشراك كافة فئات المحلي في التخطيط & 1 \\
\hline متوسطة & 1.220 & 3.24 & 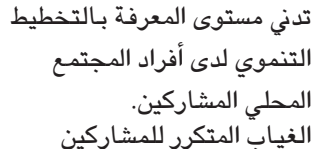 & 2 \\
\hline كبيرة & 1.141 & 3.56 & من اللقاءات والاجتمع المحلي عنات الخاصة & 3 \\
\hline كبيرة & 1.046 & 3.61 & 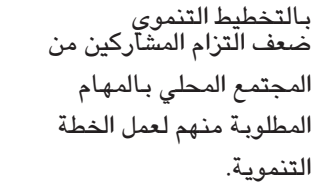 & 3 \\
\hline كبيرة & 1.072 & 3.41 & 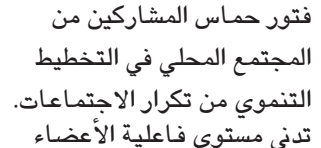 & 4 \\
\hline كبيرة & 1.027 & 3.51 & المبالقطاعات التنموينة في اللجـان الخـاصة & 5 \\
\hline كبيرة & .901 & 3.71 & المحلي على إعدار العة الخطتمة فقط. & 6 \\
\hline متوسطة & .975 & 3.27 & الخـاصة عد المشاركين في اللجـان & 7 \\
\hline كبيرة & 526. & 3.47 & \multicolumn{2}{|c|}{ مشاركة المجتمع المحلي (الدرجة الكلية) } \\
\hline
\end{tabular}

يتضح من الجدول (3) أن مستوى الصعويـات التي تواجهها

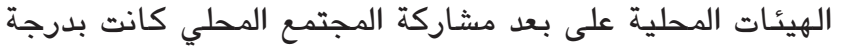

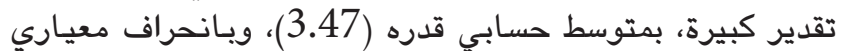

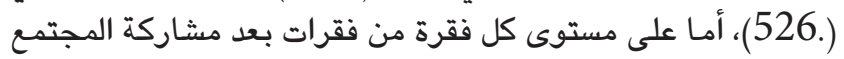

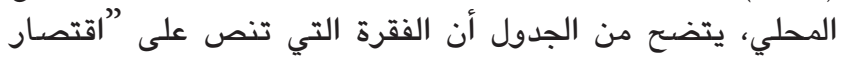

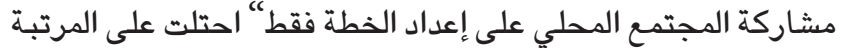

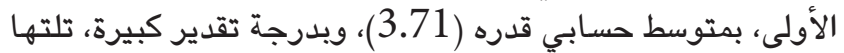

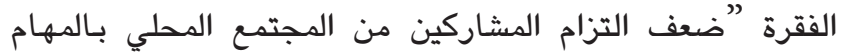

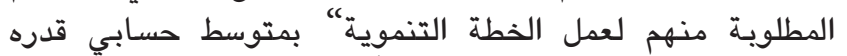

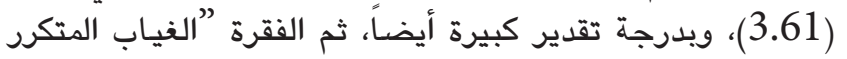

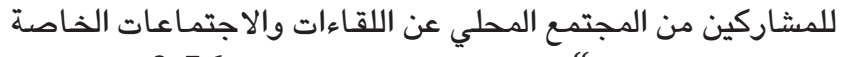

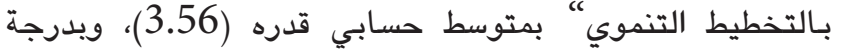

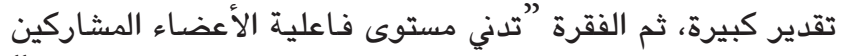

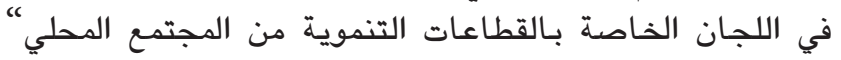
بمتوسط حسابي قدره (3.51)، ويدرجة تقدير كبيرة، تلتهات

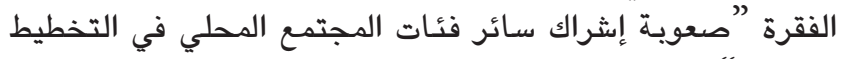

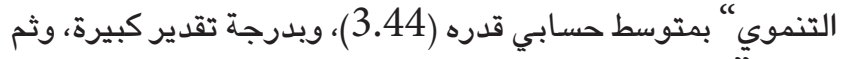

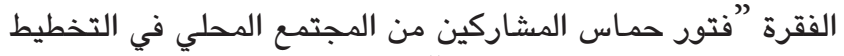

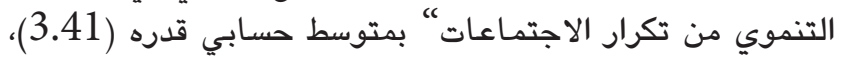

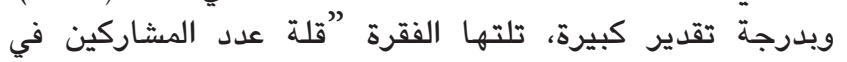




\begin{tabular}{|c|c|c|c|c|}
\hline الدرجة & المعياري & المسابي & المشكلات المتعلقة بالإجراءات & الرقم \\
\hline كبيرة & 1.165 & 3.51 & 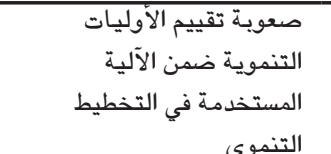 & 6 \\
\hline كبيرة & 0.661 & 3.46 & 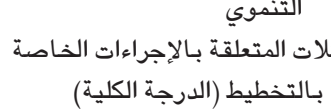 & 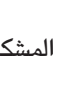 \\
\hline
\end{tabular}

يتضح من الجدول (5) أن مستوى الصعوبات التي تواجهها

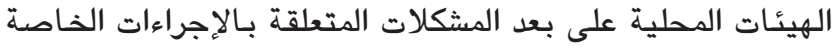

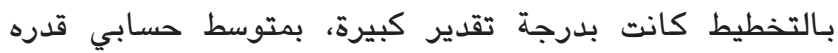

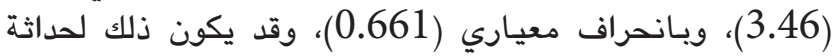

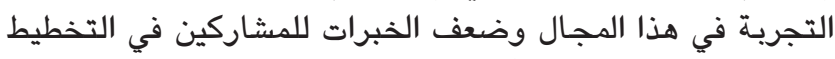

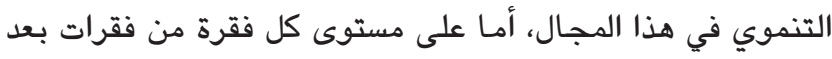

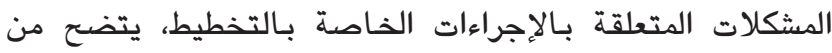

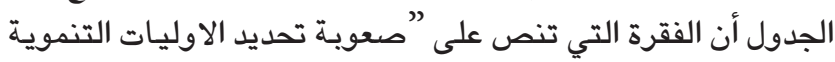

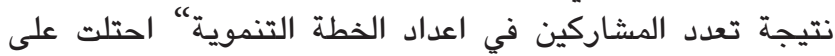

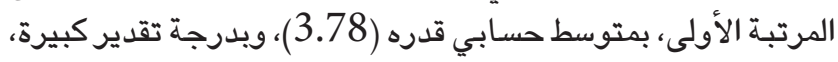

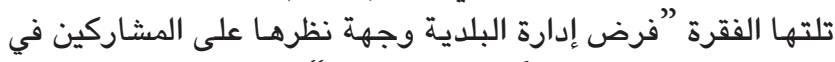

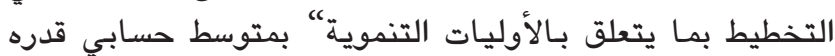

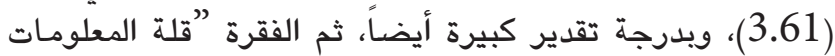

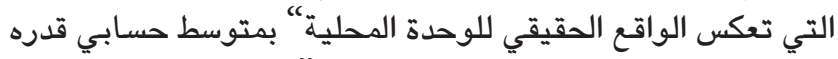

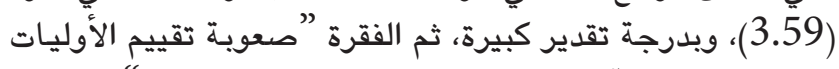

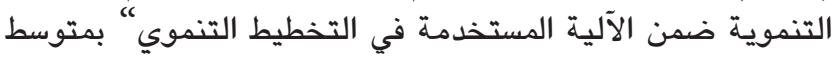

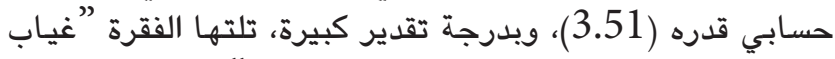

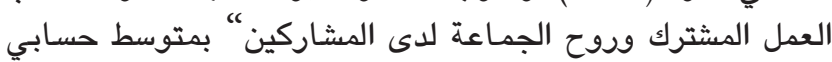

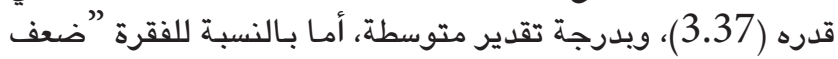

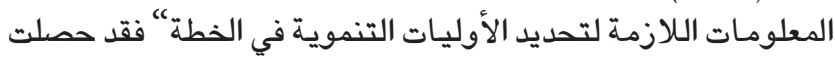

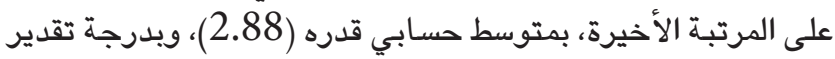

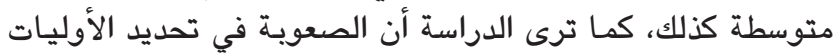

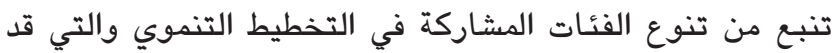
تظهر أحيانا أوليات متعارضة.

بمتوسط حسابي قدره (3.61)، ويدرجة تقدير كبيرة، وثم الفقرة

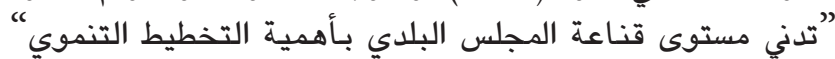

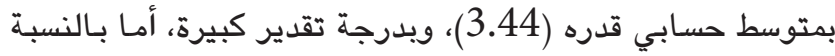

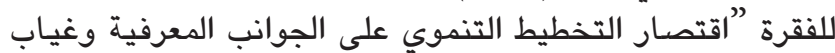

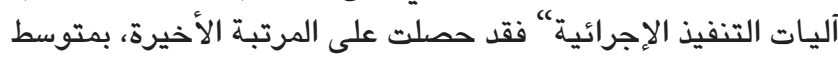

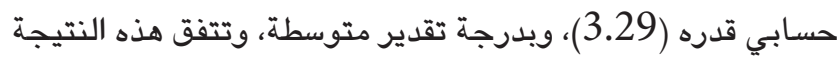

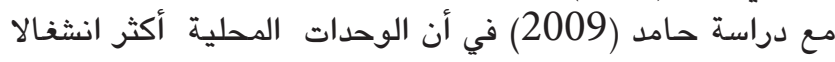

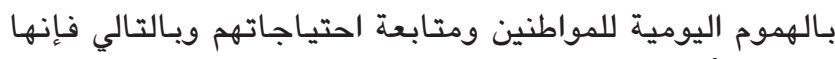

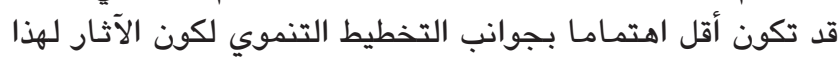

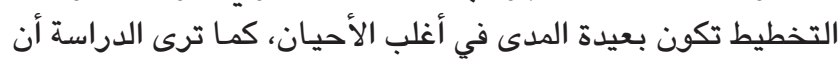

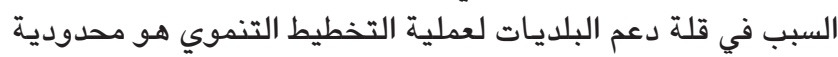

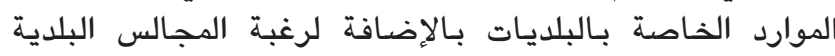

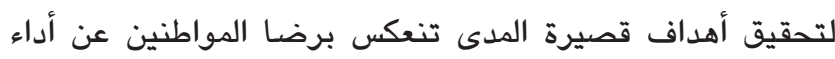

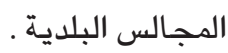

جدول (5)

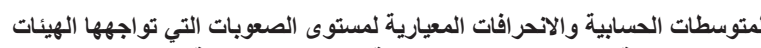

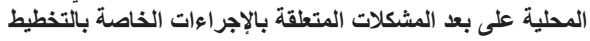

\begin{tabular}{|c|c|c|c|c|}
\hline الدرجة & الانعراف المعياري & الحستوسط الحسي & المشكلات المتعلقة بـالإجراءات & الرقم \\
\hline كبيرة & 1.095 & 3.59 & قلة المعلومات التي تعكس & 1 \\
\hline متوسطة & 1.269 & 2.88 & لتحف المعلد الأوليات التنموية اللازمة في & 2 \\
\hline كبيرة & 1.107 & 3.78 & المشاركين في إعداد الخطة التندة & 3 \\
\hline متوسطة & 1.219 & 3.37 & غياب العمل المشترك وروح & 4 \\
\hline كبيرة & 1.263 & 3.61 & 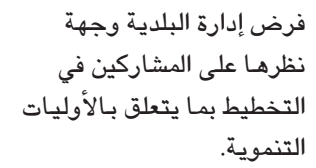 & 5 \\
\hline
\end{tabular}

جدول (6)

المتوسطات الحسابية والاتحر افات المعيارية لكل بعد من أبعاد الصعوبات التي تواجهها الهيئات المحلية على حدة، ومتوسط

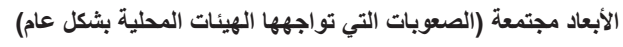

\begin{tabular}{|c|c|c|c|c|c|c|}
\hline مستوى الدلالة & "فيمة & متوسط المربعات & لدرجات & المربعات & مصدر التبـاين & المجال \\
\hline \multirow{2}{*}{0.080} & \multirow{2}{*}{2.167} & 0.663 & 5 & 3.315 & بين المجموعات & \multirow{2}{*}{ الاستشكاري والدليل المتعلقة بـالفريق } \\
\hline & & 0.306 & 35 & 10.705 & داخل المجموعات & \\
\hline \multirow{2}{*}{0.056} & \multirow{2}{*}{2.464} & 0.576 & 5 & 2.879 & بين المجموعات & \multirow{2}{*}{ مشاركة المجتمع المحلي } \\
\hline & & 0.234 & 35 & 8.177 & داخل المجموعات & \\
\hline \multirow{2}{*}{0.597} & \multirow{2}{*}{0.743} & 0.248 & 5 & 1.241 & بين المجموعات & \multirow[b]{2}{*}{ المشكلات التي تتعلق بـالبلدية } \\
\hline & & 0.334 & 35 & 11.688 & داخل المجموعات & \\
\hline \multirow{2}{*}{0.108} & \multirow{2}{*}{1.968} & 0.768 & 5 & 3.840 & بين المجموعات & \multirow{2}{*}{ المشكلات المتعلقة بـالإجراءات } \\
\hline & & 0.390 & 35 & 13.661 & داخل المجموعات & \\
\hline
\end{tabular}




\begin{tabular}{|c|c|c|c|c|c|c|}
\hline مستوى الدلالة & "فيمة & متوسط المربعات & لدرجات & المربعات & مصدر التباين & المجال \\
\hline \multirow{2}{*}{0.066} & \multirow{2}{*}{2.297} & 0.495 & 5 & 2.473 & بين المجموعات & \multirow{2}{*}{ 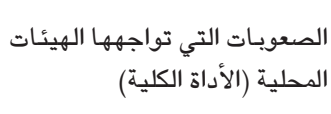 } \\
\hline & & 0.215 & 35 & 7.535 & داخل المجموعات & \\
\hline
\end{tabular}

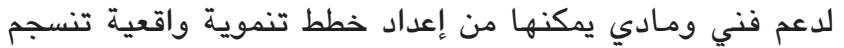

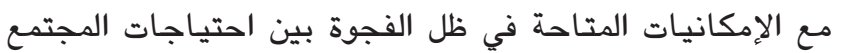

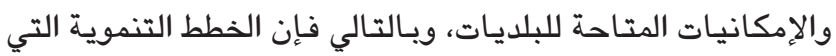

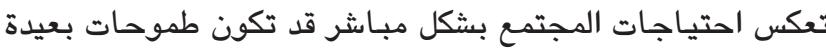

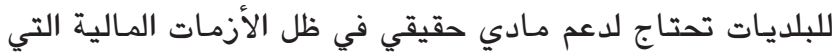

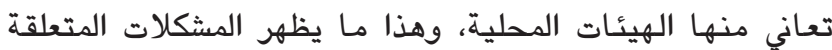
بـالبلديـات كأولى المشكلات في الدراسة.

2. النتائج المتعلقة بـالسؤال الثاني (سبل التغلب على

معيقات التخطيط):

من أجل الإجابة عن هذا السؤال تم استخراج المتوسطات

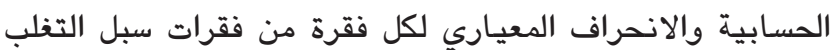

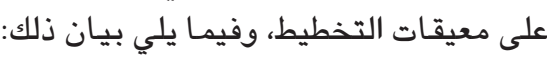

يتضح من خلال الجدول (6) أن جميع المشكلات المتعلقة

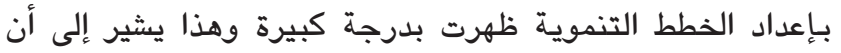

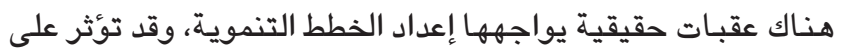
نجاحها وهذا قد يكون لحداثة التجرية ولحداثة تشكيل المجالس

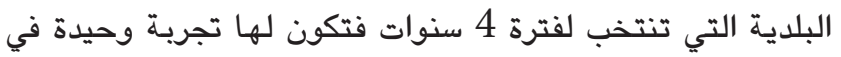

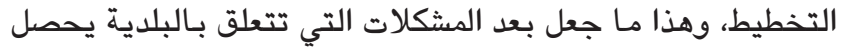

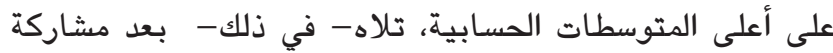

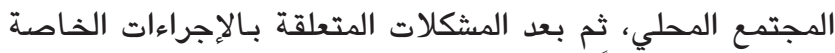

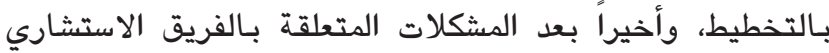

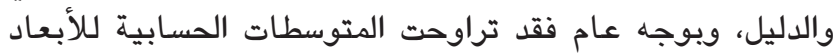
بين (3.43 - 3.62)، وكان المتوسط العام لمستوى الصعويـات

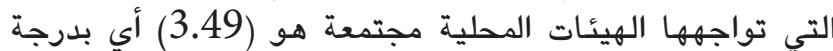
تقدير كبيرة، إذ تأتي هذه النتيجة لتعكس أن البلديات تحتاج

جدول (7)

المتوسطات الحسابية والاحر افات المعيارية لسبل التظلب على معيقات التخطيط

\begin{tabular}{|c|c|c|c|c|}
\hline الدرجة & الالعحياري & الحسابي & سبل التغلب على معيقات التخطيط & الرقم \\
\hline 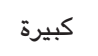 & 0.872 & 4.20 & الاستعانة بفريق استشاري متخصص ذي خبرة في مجال التخطيط التنموي للبلديات & \\
\hline كبيرة & 0.919 & 3.83 & تقبل وجهات النظر المختلفة وتجنب فرض رأي المجلس البلدي & \\
\hline كبيرة & 1.051 & 3.54 & الالتزام بدليل الإجراءات عند إعداد الخطة التنموية & \\
\hline كبيرة & 0.671 & 4.00 & تحديد الأولويات التنموية للبلدية & \\
\hline 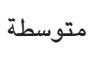 & 1.09 & 3.24 & تشجيع العمل بروح الفريق بين فريق التخطيط & \\
\hline كبيرة & 0.897 & 3.46 & تشجيع أفراد المجتمع المحلي على المشاركة المستمرة في صياغة الخطط التنموية ومتابعتها & \\
\hline كبيرة & 0.312 & 3.95 & توفير ما يلزم من بيانات ومعلومات للمشاركين في التخطيط من قبل أقسام البلدية المختلفة & \\
\hline كبيرة & 0.813 & 3.80 & العمل على تضمين الخطة بإجراءات عمل واضحة قابلة للتنفيذ & \\
\hline 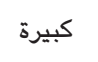 & 0.625 & 4.10 & الاستفادة من التجارب الناجحة في مجال التخطيط التنموي في البلديات & \\
\hline كبيرة & 0.758 & 3.98 & حض المشاركين في الخطة على ضرورة حضور الاجتماعات والالتزام بها & \\
\hline متوسطة & 0.990 & 3.34 & إكساب المشاركين لمهارات التخطيط التنموي في البلديات & \\
\hline 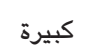 & 0.355 & 3.76 & (سبل التغلب على معيقات التخطيط (الدرجة الكلية & \\
\hline
\end{tabular}

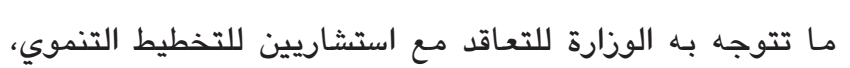

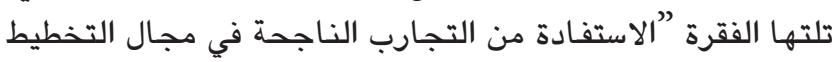

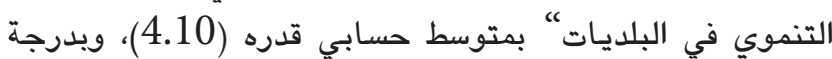

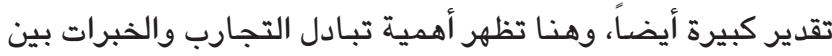

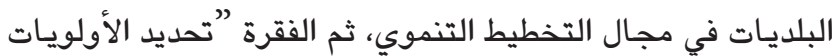

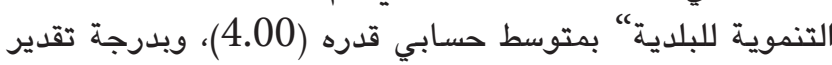
كبيرة، ثم الفقرة "حض المشاركين في الخطة على ضرورة حضور
يتضح من الجدول (7) أن مستوى توافر سبل التغلب على تلى تقدي معيقات التخطيط كان بدرجة تقدير كبيرة، بمتوسط حسابي قدره

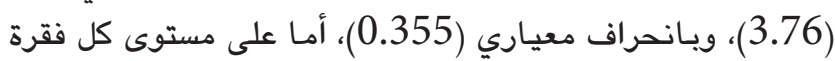

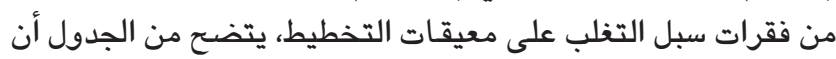

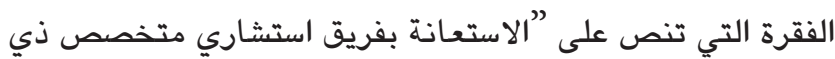

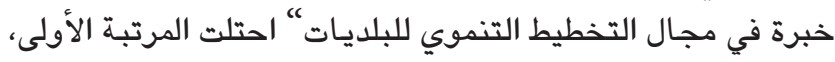
بمتوسط حسابي قدره (4.20)، وبدرجة تقدير كبيرة، وهذا يؤكد 
(3.24)، ويدرجة تقدير متوسطة.

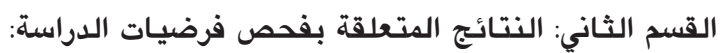

الفرضية الرئيسة الأولى:

لا توجد فروق ذات دلالة إحصائية عند مستوى الدلالة

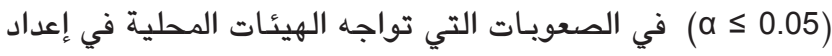

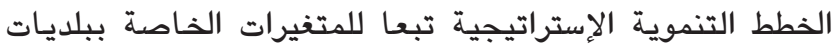

محافظات شمال الضفة الغربية.

الفرضية الفرعية الأولى: (رلا توجد فروق ذات دلالة

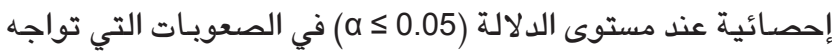

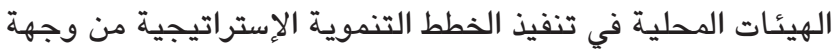

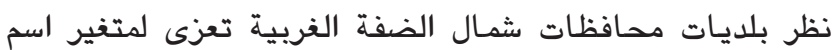

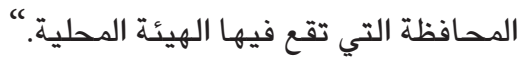

لفحص هذه الفرضية أجري اختبار تحليل التباين

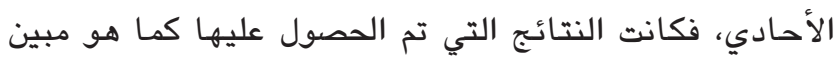

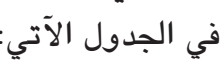

الاجتماعات والالتزام بها" بمتوسط حسابي قدره (3.98)، ويدرجة

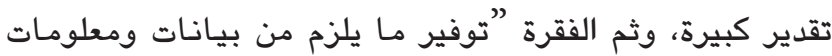

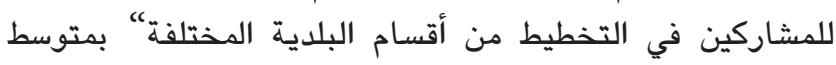

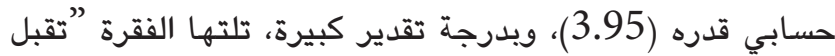

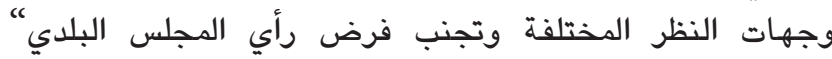

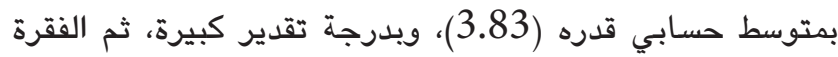

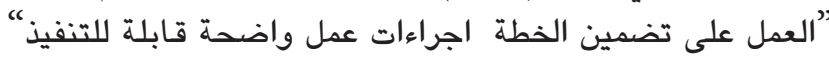
بمتوسط حسابي قدره (3.80)، ويدرجة تقدير كبيرة، وثم الفقرة

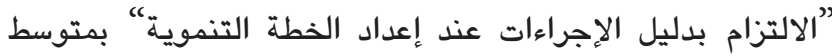

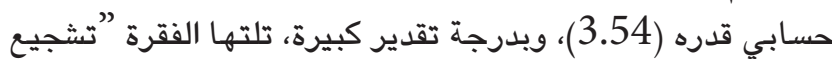
أفراد المجتمع المحلي على المشاركة المستمرة في صياغة الخطط

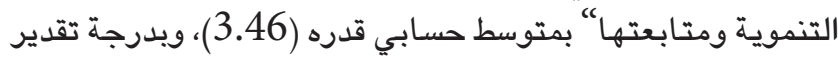

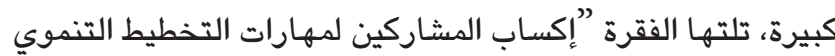
في البلديات" بمتوسط حسابي قدره (3.34)، وبدرجة تقدة تقدير

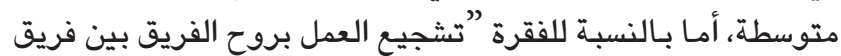

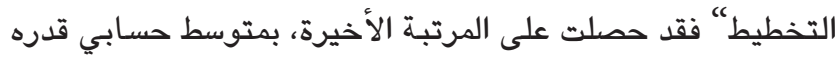

جلول (8)

\begin{tabular}{|c|c|c|c|c|c|c|}
\hline مستوى & "فيمة & متوسط & درجات & المريعات & مصدر التباين & 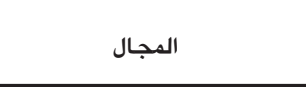 \\
\hline \multirow{2}{*}{0.080} & \multirow{2}{*}{2.167} & 0.663 & 5 & 3.315 & بين الدجموعات & \multirow{2}{*}{ الاستشاري والدليل المتلات بالفريق } \\
\hline & & 0.306 & 35 & 10.705 & داخل المجموعات & \\
\hline \multirow{2}{*}{0.056} & \multirow{2}{*}{2.464} & 0.576 & 5 & 2.879 & بين الهجموعات & \multirow{2}{*}{ مشاركة المجتمع المحلي } \\
\hline & & 0.234 & 35 & 8.177 & داخل المجموعات & \\
\hline \multirow{2}{*}{0.597} & \multirow{2}{*}{743.} & 0.248 & 5 & 1.241 & بين الهجموعات & \multirow{2}{*}{ المشكلات التي تتعلق بـالبلدية } \\
\hline & & 0.334 & 35 & 11.688 & داخل المجموعات & \\
\hline \multirow{2}{*}{0.108} & \multirow{2}{*}{1.968} & 0.768 & 5 & 3.840 & بين المجموعات & \multirow{2}{*}{ الخاصة بالتخطيطة بالإلعراءة } \\
\hline & & 0.390 & 35 & 13.661 & داخل المجموعات & \\
\hline \multirow[t]{2}{*}{0.066} & \multirow[t]{2}{*}{2.297} & 0.495 & 5 & 2.473 & بين الهجموعات & \multirow{2}{*}{ الهيئات الصحلية (الأداة الكلية) } \\
\hline & & 0.215 & 35 & 7.535 & داخل المجموعات & \\
\hline
\end{tabular}

الصفرية، أي أن مستوى الصعويـات التي تواجهها الهيئات المحلية

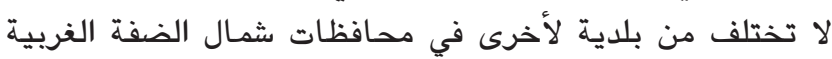
بـاختلاف اسم المحافظة التي تقع فيها الهيئة المحلية. الفرضية الفرعية الثانية: (الا توجد فروق ذات دلالة

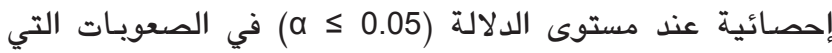

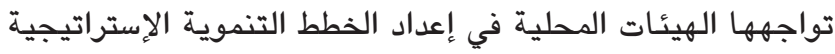

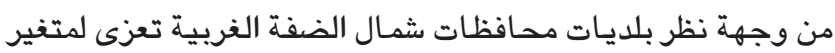
تصنيف الهيئة الهحلية. ، بلهات لفحص هذه الفرضية أجري اختبار تحليل التباين الأحادي، فكانت النتائج التي تم الحصول عليها كما هو مبين في الجدول
يتضح من الجدول (8) عدم وجود فروق ذات دلالة إحصائية

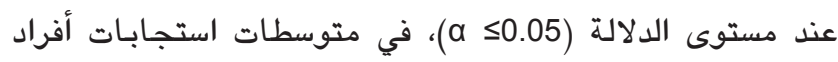

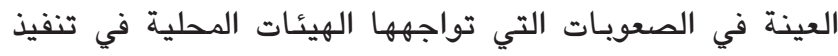

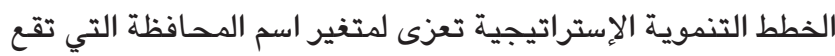
فيها الهيئة المحلية، وذلك على مستوى الصعويـات التي تواجهها

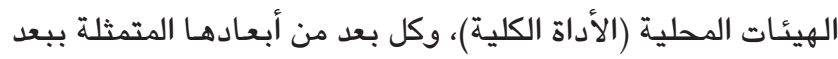

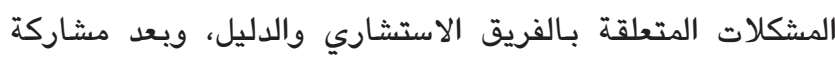

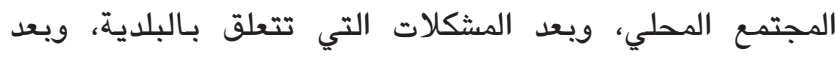

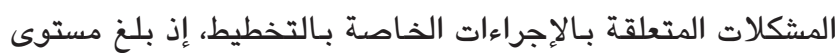

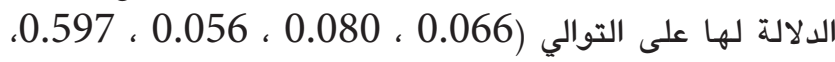
0.108)، وهذه القيم أكبر من (0.05)، مدا يعني قبول الفرضية 
جدول (9)

\begin{tabular}{|c|c|c|c|c|c|c|}
\hline مستوى - الدلالة & "فيمة & متوسط المربعات & 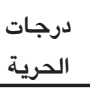 & المربـعات & مصدر التباين & المجال \\
\hline \multirow{2}{*}{0.065} & \multirow{2}{*}{2.948} & 0.942 & 2 & 1.883 & بين المجموعات & \multirow{2}{*}{ الاسشتشاري المتعلقة بـالفريق } \\
\hline & & 0.319 & 38 & 12.137 & داخل المجموعات & \\
\hline \multirow{2}{*}{0.008} & \multirow{2}{*}{5.479} & 1.237 & 2 & 2.475 & بين المجموعات & \multirow{2}{*}{ مشاركة المجتمع الهحلي } \\
\hline & & 0.226 & 38 & 8.581 & داخل المجموعات & \\
\hline \multirow{2}{*}{0.008} & \multirow{2}{*}{5.431} & 1.437 & 2 & 2.874 & بين المجموعات & \multirow{2}{*}{ المشكلات التي تتعلق بـالبلدية } \\
\hline & & 0.265 & 38 & 10.055 & داخل المجموعات & \\
\hline \multirow{2}{*}{0.001} & \multirow{2}{*}{9.178} & 2.850 & 2 & 5.700 & بين المجموعات & \multirow{2}{*}{ النشاصكة بـالتخطيط المتعلقة بـالإجراءات } \\
\hline & & 0.311 & 38 & 11.801 & داخل المجموعات & \\
\hline \multirow{2}{*}{0.001} & \multirow{2}{*}{8.046} & 1.489 & 2 & 2.977 & بين المجموعات & \multirow{2}{*}{ الهيئات المحلية (الأداة الكلية) } \\
\hline & & 0.185 & 38 & 7.030 & داخل المجموعات & \\
\hline
\end{tabular}

المشكلات التي تتعلق بـالبلدية، ويعد المشكلات المتعلقة بـالإجراءات

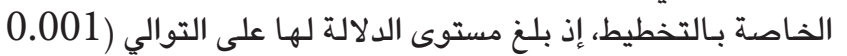

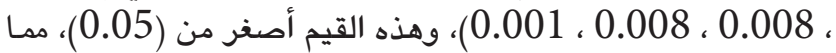

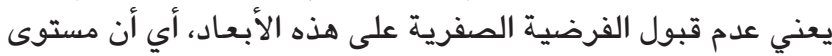

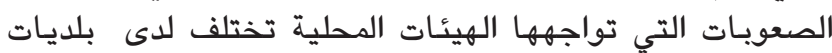
محافظات شمال الضفة الغربية بـاختلاف تصنيف الهيات الهيئة المحلية وذلك على مستوى الصعويـات التي تواجهها الهيئات المحلية (الأداة الكلية)، وكل من بعد مشاركة المجتمع المحلي، وبعد المشكلات

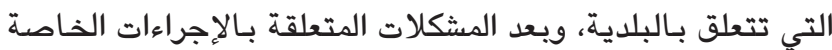

بـالتخطيط.

وللتعرف إلى مواطن الفروق في الصعويـات التي تواجهها

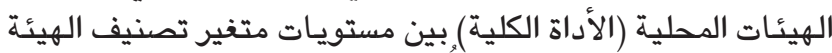

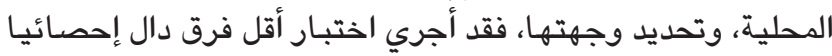

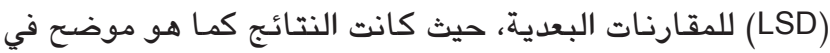

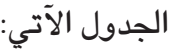

يتضح من الجدول (9) عدم وجود فروق ذات دلالة إحصائية

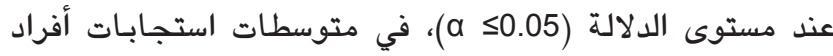

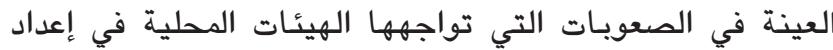
الخطط التنموية الإستراتيجية تعزى لمتغير تصنيف الهيئة المحلية،

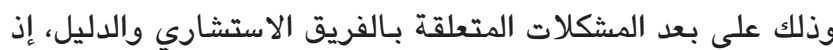

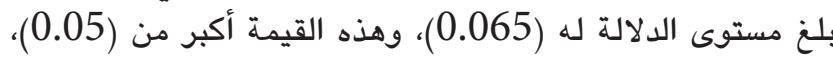

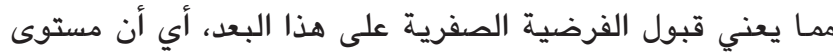

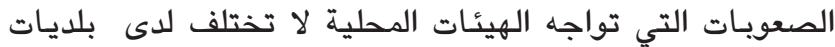

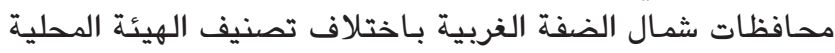
وذلك على بعد المشكلات المتعلقة بـالفريق الاستشاري والداليل. في حين تبين وجود فروق ذات دلالة إحصائية في متوسطات

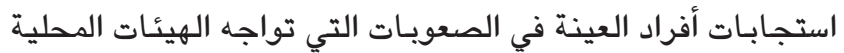

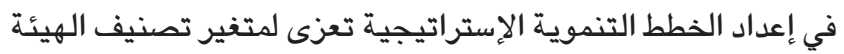

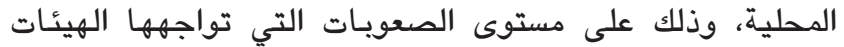
المحلية (الأداة الكلية)، وكل من بعد مشاركة المجتمع المحلي، ويعد

جدول (10)

\begin{tabular}{|c|c|c|c|}
\hline المتوسط (3.66) & المتوسط (3.41) & المتوسط (2.84) & تصنيف الهيئة الهحلية \\
\hline${ }^{\times}-0.82857-$ & ${ }^{\times}-0.57013-$ & --------- & المتوسط (2.84) \\
\hline$-0.25844-$ & --------- & & المتوسط (3.41) \\
\hline -------- & & & المتوسط (3.66) \\
\hline
\end{tabular}

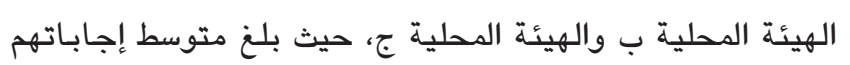
على التوالي (3.41 ، 3.66)، مقابل متوسط إجابـات الهيئة المحلية الهـية

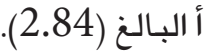

يشير الجدول (10) إلى أن الفروق بين إجابـات أفراد العينة

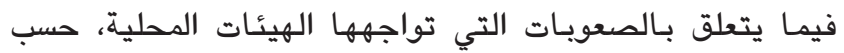
متغير تصنيف الهيئة المحلية، كانت بين الهيئة المحلية أ في جهة،

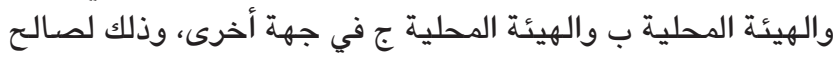


الفرضية الفرعية الثالثة: (لا توجد فروق ذات دلالة عدد السكان في البلدة/المدينة. “

لفحص هذه الفرضية أجري اختبار تحليل التباين الأحادي،

فكانت النتائج التي تم الحصول عليها كما هو مبين في الجدول

الآتي:

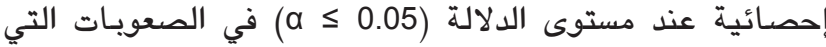

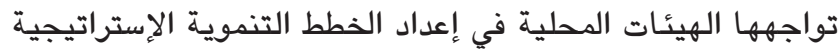

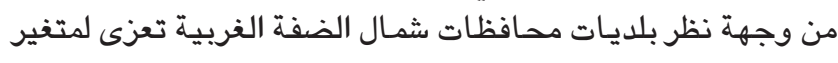

جدول (11)

نتائج اختبار تحليل التباين الأحادي، لاختبار مستوى دلالة الفروق بحسب متغير عدد السكان في البلاة/المدينة

\begin{tabular}{|c|c|c|c|c|c|c|}
\hline مستوى الدلادة & "فيمة & المربعات & درجات & المربعـات & مصدر التباين & المجال ل \\
\hline \multirow{2}{*}{0.188} & \multirow{2}{*}{1.682} & 0.561 & 3 & 1.682 & بين المجموعات & \multirow{2}{*}{ الاستكلات المتعلقة بالفريق الداريل } \\
\hline & & 0.333 & 37 & 12.338 & داخل المجموعات & \\
\hline \multirow{2}{*}{0.027} & \multirow{2}{*}{3.428} & 0.801 & 3 & 2.404 & بين المجموعات & \multirow{2}{*}{ مشاركة المجتمع المحلي } \\
\hline & & 0.234 & 37 & 8.651 & داخل المجموعـات & \\
\hline \multirow{2}{*}{0.009} & \multirow{2}{*}{4.447} & 1.142 & 3 & 3.426 & بين المجموعات & \multirow{2}{*}{ المشكلات التي تتعلق بـالبلدية } \\
\hline & & 0.257 & 37 & 9.503 & داخل الدجموعات & \\
\hline \multirow{2}{*}{0.042} & \multirow{2}{*}{3.014} & 1.146 & 3 & 3.437 & بين المجموعات & \multirow{2}{*}{ المشكلات المتعلقة بالإجراءات } \\
\hline & & 0.380 & 37 & 14.064 & داخل المجموعات & \\
\hline \multirow{2}{*}{0.010} & \multirow{2}{*}{4.324} & 0.866 & 3 & 2.598 & 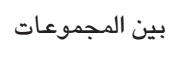 & \multirow{2}{*}{ 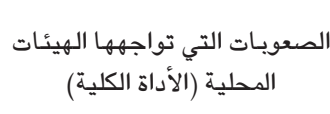 } \\
\hline & & 0.200 & 37 & 7.410 & داخل المجموعات & \\
\hline
\end{tabular}

المحلي، ويعد المشكلات التي تتعلق بـالبلدية، ويعد المشكلات

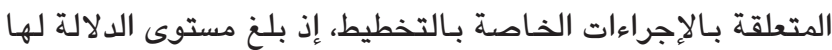

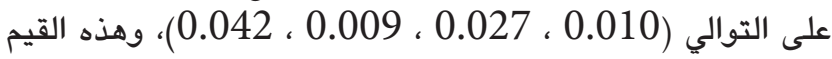

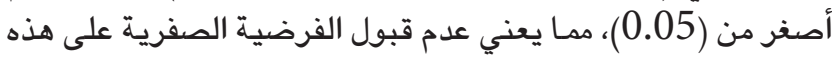

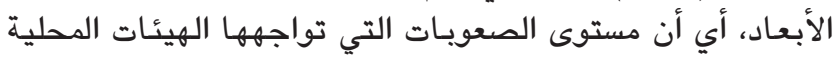

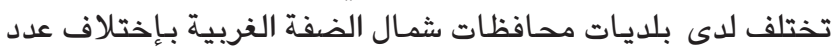

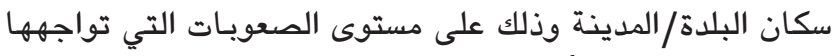

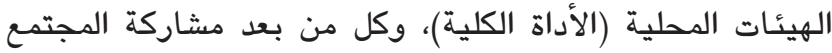

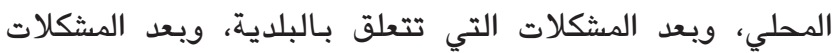
المتعلقة بـالإجراءات الخاصة بـالتخطيط.

وللتعرف على مواطن الفروق في الصعويـات التي تواجهها

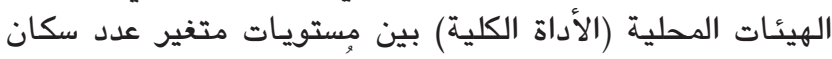

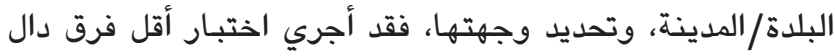

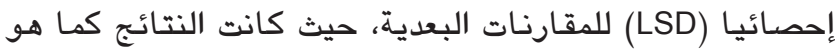

موضح في الجدول الآتي:
يتضح من الجدول (11) عدم وجود فروق ذات دلالة إحصائية

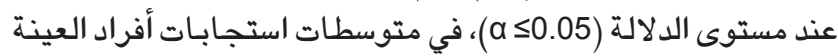

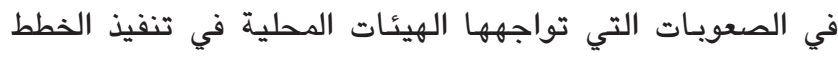
التنموية الإستراتيجية تعزى لمتغير عدد سكان البلدة/المدينة،

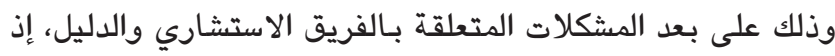

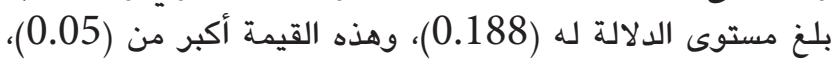

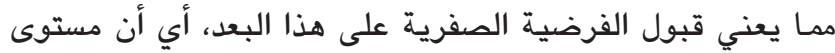

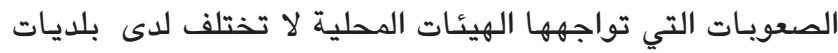

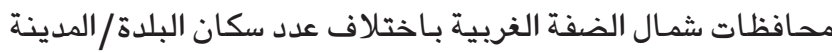

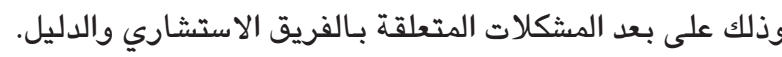
في حين تبين وجود فروق ذات دلالة إحصائية في متوسطات

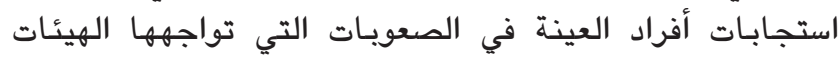

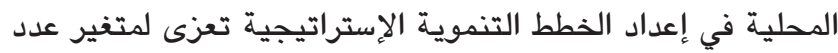

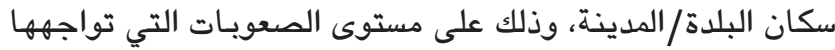

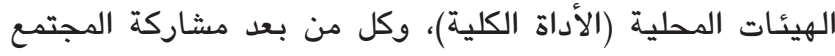

جلول (12)

اختبار أقل فرق دال إحصائيا (LSD) للمقارنات البعدية للصعوبات التي تواجهها الهيئات المحلية تعزى لمتفير عدد سكان البلدة/المدينة

\begin{tabular}{|c|c|c|c|c|}
\hline أكثر من 50000 المتوسط (2.83) & $\begin{array}{c}\text { (المتوسط (20000 - (3.09) } \\
\text { (3.000) }\end{array}$ & $\begin{array}{c}\text { (المتوسط (3.60) - } 10000) \\
\text { (3.699) }\end{array}$ & أقل من 10000 المتوسط (3.62) & عدد سكان البلدة/ المدينة \\
\hline${ }^{\times} 0.78617$ & $\times 0.52665$ & 0.02257 & -------- & أقل من 10000 المتوسط (3.62) \\
\hline${ }^{\times} 0.76361$ & 0.50408 & --------- & & $\begin{array}{c}\text { (المتوسط (10000 19999) } \\
\text { (3.60) }\end{array}$ \\
\hline
\end{tabular}




\begin{tabular}{|c|c|c|c|c|}
\hline أكثر من 50000 المتوسط (2.83) & 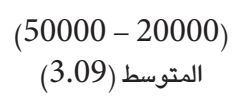 & (19999 - 19900) & أقل من 10000 المتوسط (3.62) & عدد سكان البلدة/ المدينة \\
\hline 0.25952 & -------- & & & (30000 - 20000 - (3.09) \\
\hline---- & & & & أكثر من 50000 المتوسط (2.83) \\
\hline
\end{tabular}

50000، وذلك لصالح البلدة/المدينة التي عدد سكانها تراوح بين

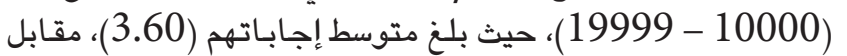
متوسط إجابات البلدة/المدينة التي عدد سكانها أكبر من 50000 البالغ (2.83).

الفرضية الفرعية الرابعة: (الا توجد فروق ذات دلاتلة

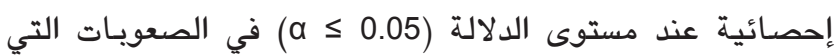

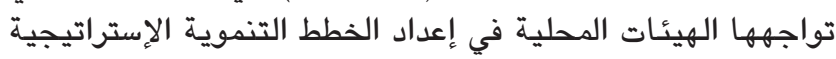

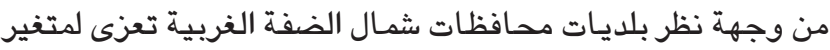

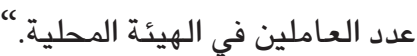
لفحص هذه الفرضية أجري اختبار تحليل التباين الأحسادي،

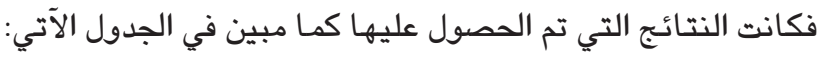

يشير الجدول (12) إلى أن الفروق بين إجابـات أفراد العينة

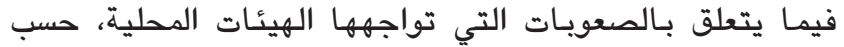

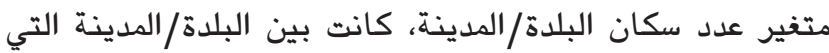

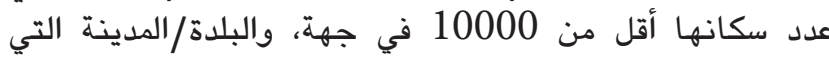

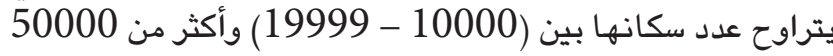
في جهة أخرى، وذلك لصالح البلدة/المدينة التي عدد سكانها أقل

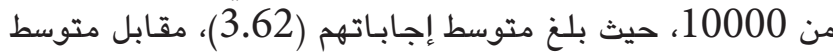

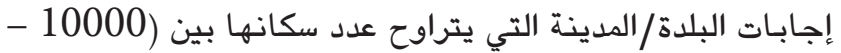
19999) وأكثر من البدات الدينة 50000 البالغ على التوالي (3.60 ، 3. 3.09)،

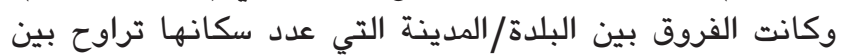

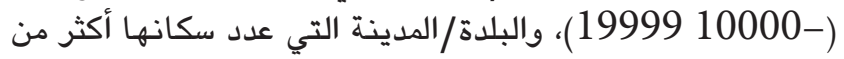

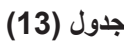

\begin{tabular}{|c|c|c|c|c|c|c|}
\hline مستوى الدلادة & "فيمة & متوسط المريعات & درجات & المريعات & مصدر التباين & 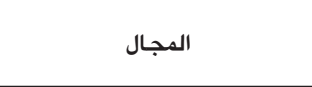 \\
\hline \multirow{2}{*}{0.105} & \multirow{2}{*}{2.196} & 0.706 & 3 & 2.119 & بين الهجموعات & \multirow{2}{*}{ الاستشاري والدليل المتعة بالفريق } \\
\hline & & 0.322 & 37 & 11.901 & داخل الدجموعات & \\
\hline \multirow{2}{*}{0.013} & \multirow{2}{*}{4.099} & 0.919 & 3 & 2.758 & بين الدجموعات & \multirow{2}{*}{ مشاركة المجتمع المحلي } \\
\hline & & 0.224 & 37 & 8.298 & داخل المجموعات & \\
\hline \multirow{2}{*}{0.003} & \multirow{2}{*}{5.507} & 1.330 & 3 & 3.991 & بين المجموعات & \multirow{2}{*}{ المشكلات التي تتعلق بالبلدية } \\
\hline & & 0.242 & 37 & 8.938 & داخل الدجموعات & \\
\hline \multirow{2}{*}{0.007} & \multirow{2}{*}{4.719} & 1.614 & 3 & 4.843 & بين المجموعات & \multirow{2}{*}{ الخاصة بالتخطيط المتعلة بالإجراءات } \\
\hline & & 0.342 & 37 & 12.658 & داخل المجموعات & \\
\hline \multirow{2}{*}{0.002} & \multirow{2}{*}{5.751} & 1.061 & 3 & 3.182 & بين المجموعات & \multirow{2}{*}{ الهيئات المحلية (الأداة الكلية) } \\
\hline & & 0.184 & 37 & 6.825 & داخل المجموعات & \\
\hline
\end{tabular}

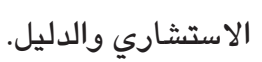

في حين تبين وجود فروق ذات دلالة إحصائية في متوسطات

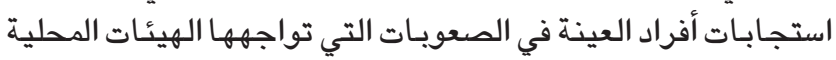
في إعداد الخطط التنموية الإستراتيجية تعزى لمتغير الهير عدد العاملين في الهيئة المحلية، وذلك على مستوى الصعويـات التي تواجهها الهيئات المحلية (الأداة الكلية)، وكل من بعلية معد مشثاركة المجتمع

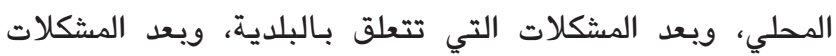

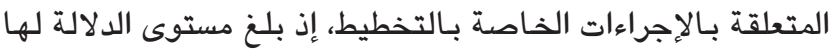

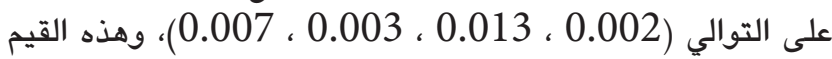

يتضح من الجدول (13) عدم وجود فروق ذات دلالة إحصائية عند مستوى الدلالة (0.05 م)، في متوسطات استجابـات

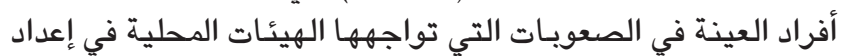

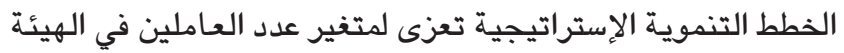

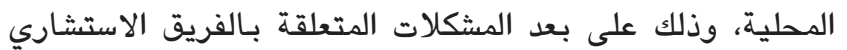

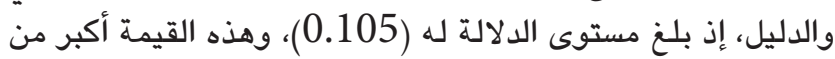

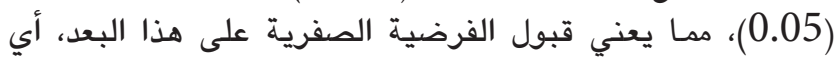

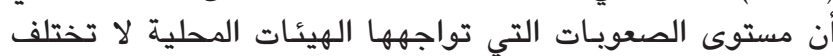

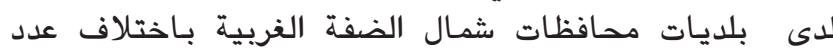

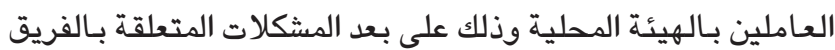


اختبار معامل الارتباط ( بيرسون)، وفيما يلي توضيح ذلك:

جدول (15)

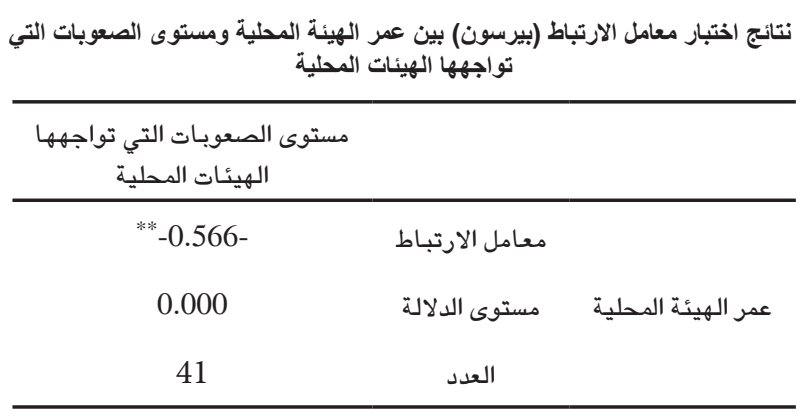

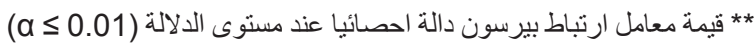

يتضح من الجدول (15) وجود علاقة خطية سالبة وقوية

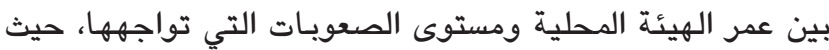

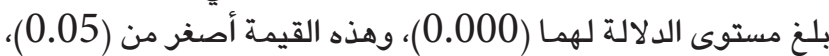

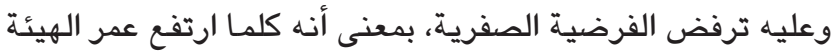

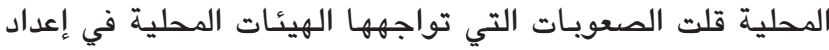
الخطط التنموية الإستراتيجية من وجهة نظر بلدية تلديات محافظات شمال الضفة الغربية، والعكس صحيح.

\section{تلخيص النتائج:}

1. ظهرت المشكلات المتعلقة بـالبلدية كأكبر المشكلات

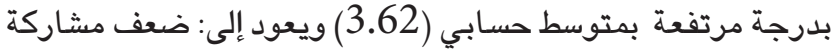

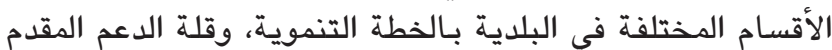

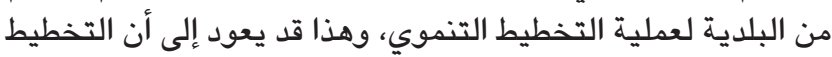

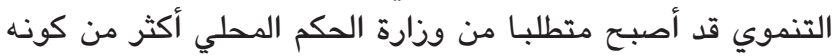

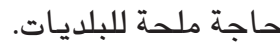

2. ظهرت المشكلات المتعلقة بـالمجتمع المحلي بلدرجة

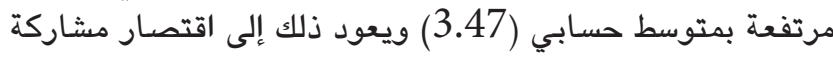

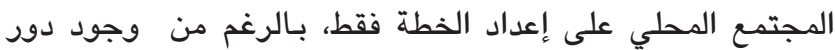

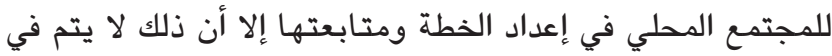

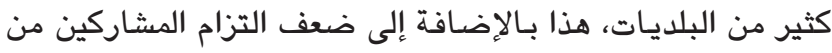

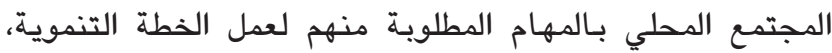

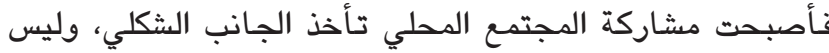

الجـانب الفاعل في المشاركة الحقيقية في إعداد الخطة.

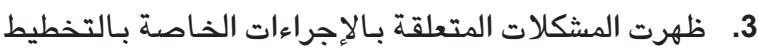

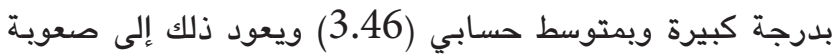
تحديد الأوليات التنموية نتيجة تعدد المشاركين في إعداد الخطة

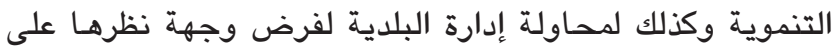

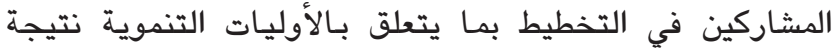

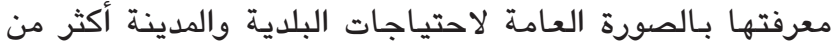

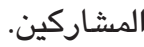

4. ظهرت المشكلات المتعلقة بـالفريق الاستشاري والدليل بلدجة كبيرة أيضا بمتوسط حسابي (3.43) وذلك يعود إلى تدني مستوى وضوح مراحل التخطيط التنموي وفق ما نصا نص عليه الدليل

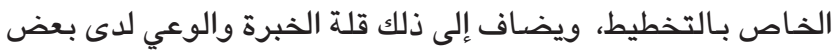

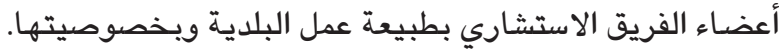

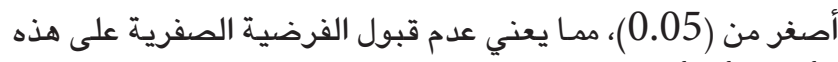

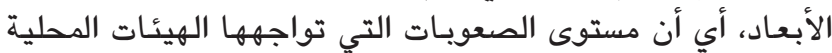

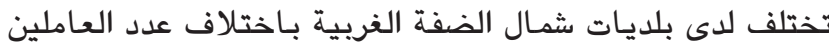

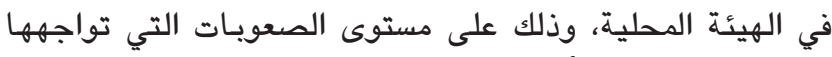

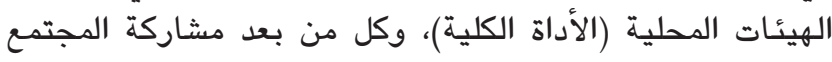

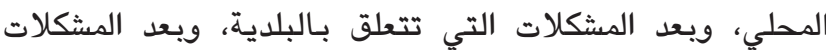
المتعلقة بـالإجراءات الخاصة بـالتخطيط.

وللتعرف على مواطن الفروق في الصعويـات التي تواجهها

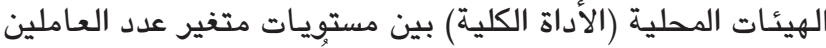

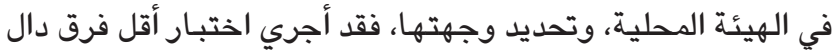

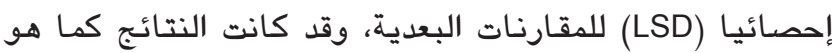
موضسح في الجدول الآتي:

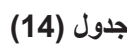

ختبار أقل فرق دال إحصائيا (LSD) للمقارنات البعدية للصعوبات التي تواجهها الهيئات المحلية تعزى لمتغير عدد العاملين في الهيئة المحلية المئية

\begin{tabular}{|c|c|c|c|c|}
\hline المتوسط 200 ذأكثر & $\begin{array}{c}199-50 \\
\text { المتوسط } \\
\text { (3.06) }\end{array}$ & $\begin{array}{l}49-20 \\
\text { المتوسط } \\
\text { (3.54) }\end{array}$ & أقل من 20 المتوسط & في الهديئة العاملين \\
\hline *0.83095 & *0.60476 & 0.12347 & --------- & أقل من 20 المتوسط \\
\hline *0.70748 & 0.48129 & -------- & & $\begin{array}{l}49-20 \\
\text { المتوسط } \\
\text { (3.54) }\end{array}$ \\
\hline 0.22619 & -------- & & & $\begin{array}{c}199-50 \\
\text { المتوسط } \\
\text { (3.06) }\end{array}$ \\
\hline -------- & & & & 200 نأكثر \\
\hline
\end{tabular}

يشير الجدول (14) إلى أن الفروق بين إجابـات أفراد العينة

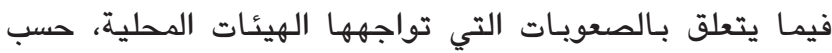

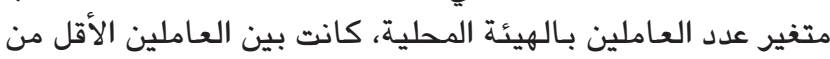

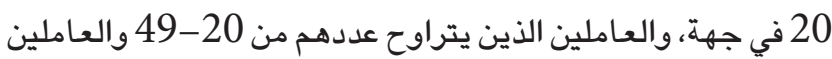

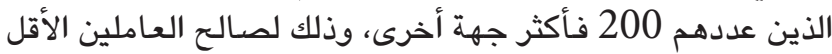

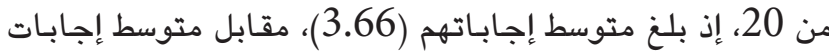

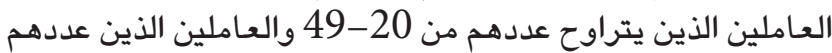

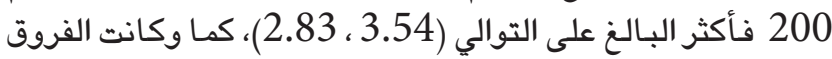

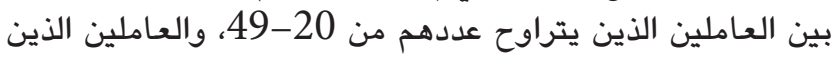
عددهم200 فأكثر، وذلك لصالح العاملين الذين يتراوح عنداون عددهم

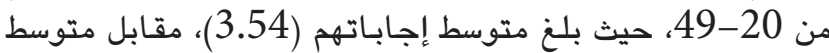

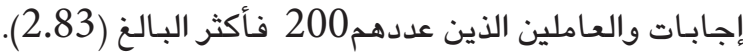

الفرضية الرئيسة الثانية: (الا توجد علاقة ذات دلالة

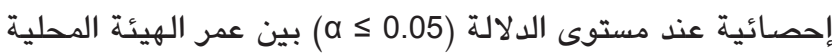

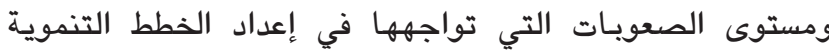
الإستراتيجية من وجهة نظر بلديات محافظات شمال الضفة

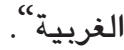

لفحص وجود علاقة ارتباطيه بين عمر الهيئة المحلية

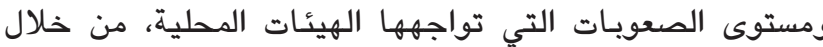


انتهجتها الهيئات المحلية عند عمل خططها التنموية حيث تمثل

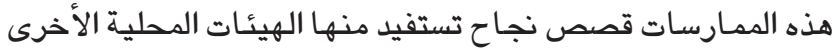

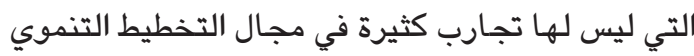
5. تقديم حوافز مادية ومعنوية للمشاركين من المجتمع

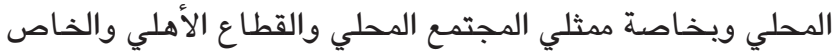

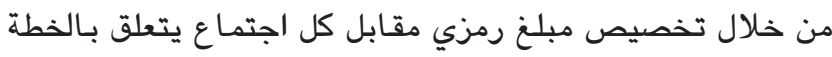

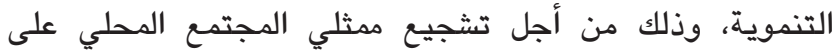

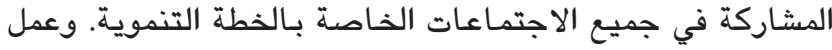

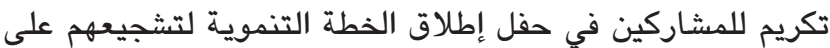

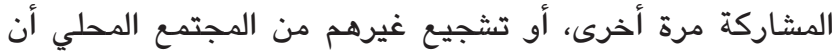
يكونوا ضمن المشاركين في إعداد الخطط التنموية المستقبلية.

\section{المراجع}

\section{المراجع العربية: - أملية}

1. البطحة، رائد محمود، (2017)، مدى تطبيق التخطيط التنموي الاستراتيجي لدى بلديات محافظة بيت لحم من وجهة منول، نظر أعضاء

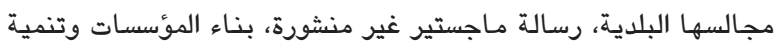
الموارد البشرية،،جامعة القدس.فلسطين. حامد، راشد عبد العزيز احمد، (2009)، استراتيجية تطوير الهيئات الهحلية

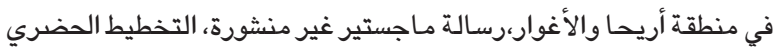
والاقليمي، كلية الدراسات العليا، جامعة النجاح الوطنية،نابلس،فلسطين. 3. الزهار، ريم محمود، (2014)، دراسة واقع تطبيق الخطط التنموية

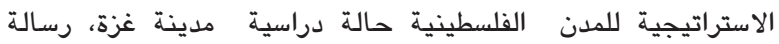
ماجستير غير منشورة، قسم الهندسة المعمارية،كلية الهندسة الجامعة الإسلامية،غزة، فلسطين. - اجين. صبيح، ماجد، (2011)، التنمية الاقتصادية، منشورات جامعة القدس راس

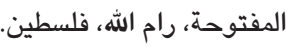
العارف، نادية . (2001) التخطيط الاستراتيجي والعولمة، الدار الجامعية،

ابن عثمان، شويح، (2011)، دور الجماعات المحلية في التنمية الدحلية -

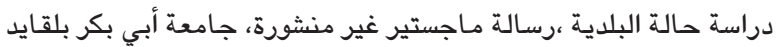

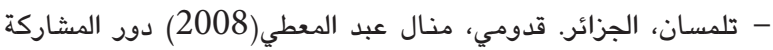

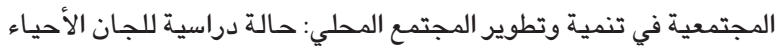

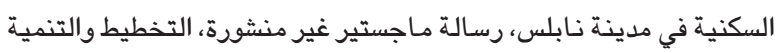

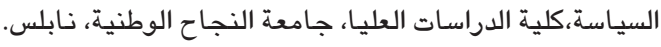

7. القيق، فريد، (2014)، دور المشاركة المجتمعية في تحقيق التنمية

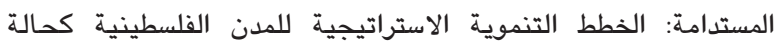
دراسية، مجلة فلسطين لابحاث والدراسات،فبراير.

ناصر، فواز حسين سعيد، (2014)، نموذج قبلان في التخطيط التنموي

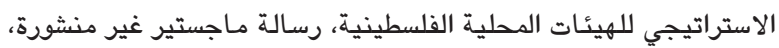

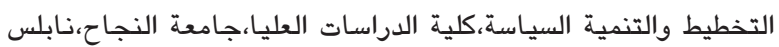

نلسطين.

الهموز، إبراهيم مسعود إسماعيل،(2008)،اتجاهـات التخطيط التنموي

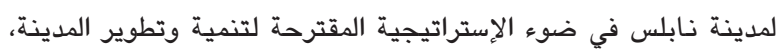
رسالة ماجستير غير منشورة، التخطيط الحضري والاقليمي، كلية

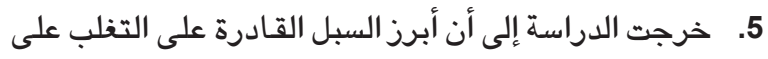

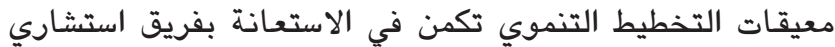

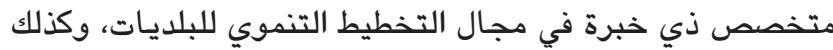

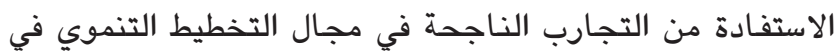
البلديات.

6. أظهرت النتائج أنه لا توجد علاقة ذات دلالة إحصائية

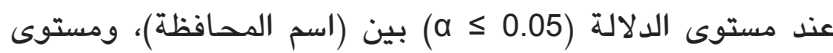
الصعويـات التي تواجهها في إعداد الخطط التنموية الإستراتيجية من وجهة نظر البلديات محافظات شمال الضفة الغربية، بينما ظهرت فروق في المتغيرات (تصنيف الهيئة المحلية، عمر الهيئة،

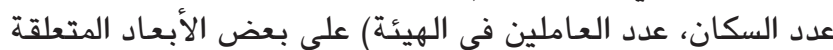

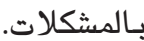

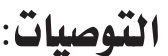

من خلال النتائج التي تمخضت عنها الدراسة فـإنها تقدم

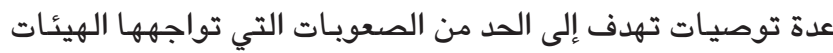

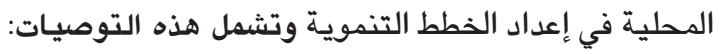
1. ر رغم أهمية الفريق الاستشاري في مساعدة المشاركين في

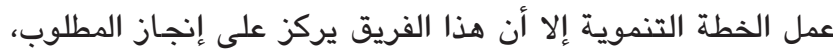

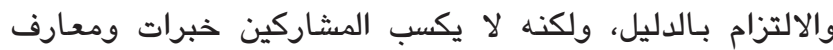
منظمة، تمكنهم من إعداد خطط تنموية مستقبلية دون الاستية لاستعانة

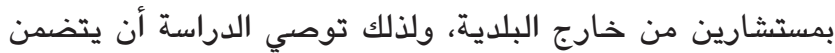

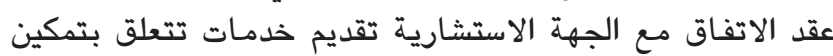

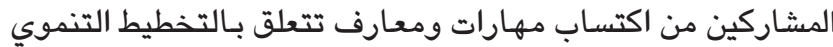

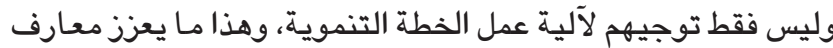

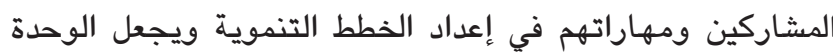

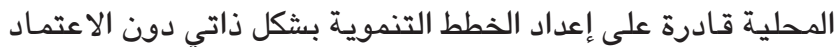
على المستشارين الخـارجيين.

2. رغم أهمية الدليل الإرشادي الخاص بـالخطة التنموية

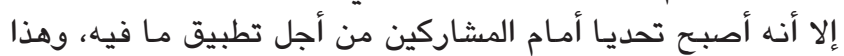

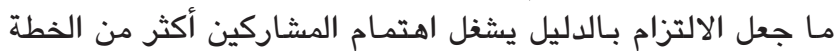

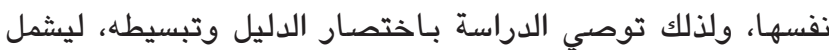
الأدوات الرئيسة للتخطيط، ومن ثم ترك هـامش أوسع للوحدات

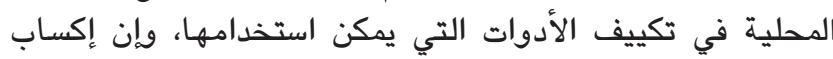

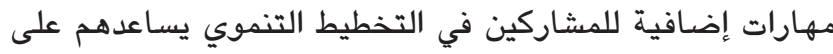

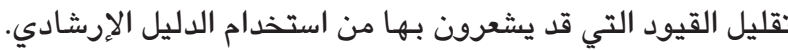
3. إن تكرار عمل الخطط التنموية من قبل الهيئات المحلية

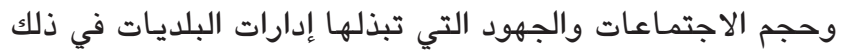
جعل إدارات بعض البلديات تشعر أن الخطط التنموية أصبحت

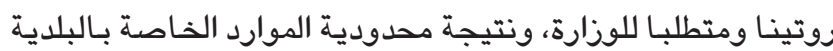

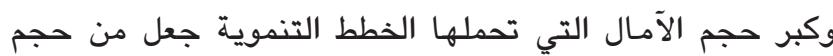

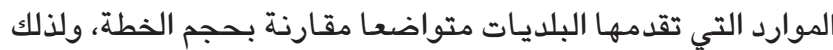

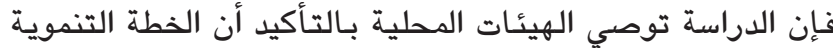

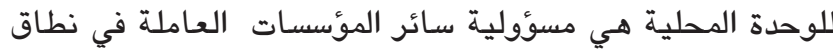
الوحدة المحلية من قطاع خاص هي مولية وعام وأهلي وليست مسؤولية الهيئة المحلية فقط المحلة فئ

4. توصي الدراسة بتعميم الممارسات الجيدة التي قد 


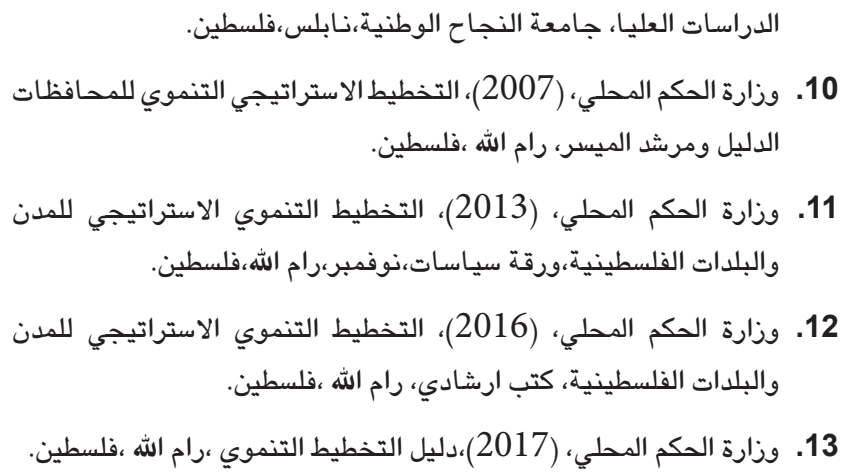

1. Barcson, B. S. (2015). Challenges to implementing of development plans at local-level government in Papua New Guinea. Commonwealth Journal of Local Governance, (16/17), 150.

2. Dyadik, V. (2014). Strategic planning at the municipal level: Russian challenges and Nordic practices. BARENTS STUDIES: Peoples, Economies and Politics, VOL. 1, issue 2.

3. Machaka, E. S. (2012). Local Economic Development (LED) challenges facing the Local Government in the Limpopo Province: the case of Motumo Trading Post in the Molemole Local Municipality of the Capricorn District Municipality(Doctoral dissertation). University of Limpopo.

4. Shittu, A. I., \& Musbaudeen, A. M. (2016). Public Participation in Local Government Planning and Development: Evidence from Lagos State, Nigeria. Covenant University Journal of Politics and International Affairs, 2(3).

5. Thanyani Selby Madzivhandila \& Maloka Caswel. (2014). Community Participation in Local Government Planning Processes: A Paramount Step Towards a Successful Service Delivery, Mediterranean Journal of Social Sciences, MCSER Publishing, Rome-Italy, Vol 5 No 16 ,July 2014

6. Government of Alberta.(2018). Guidebook For Preparing A Municipal Development Plan, Canada,p4;

7. Arch, Nicolae Taralunga,(2010), Introduction Of Comprehensive Participation Of Citizens As Well As Governmental And Non-governmental Organizations In The Urban Planning Process,Macedonia, January 2010.p14.

8. Community Planning Branch,(2011), A Guide to the Municipal Planning Process in Saskatchewan, August 2011,p3 